NBER WORKING PAPER SERIES

\title{
GENDER DIFFERENCES IN COVID-19 RELATED ATTITUDES AND BEHAVIOR: EVIDENCE FROM A PANEL SURVEY IN EIGHT OECD COUNTRIES
}

\author{
Vincenzo Galasso \\ Vincent Pons \\ Paola Profeta \\ Michael Becher \\ Sylvain Brouard \\ Martial Foucault \\ Working Paper 27359 \\ http://www.nber.org/papers/w27359 \\ NATIONAL BUREAU OF ECONOMIC RESEARCH \\ 1050 Massachusetts Avenue \\ Cambridge, MA 02138 \\ June 2020
}

Vincenzo Galasso, Vincent Pons and Paola Profeta did the conceptualization of the research question, the data curation, the formal analysis, and the writing of the paper. Michael Becher, Sylvain Brouard and Martial Foucault provided comments to the final draft. Nicola Bariletto, Marco Lo Faso, and Nicolas Longuet Marx provided excellent research assistance. Survey data from the project Attitudes on COVID-19: A Comparative Study, chaired by Sylvain Brouard and Martial Foucault (Sciences Po). Financial Support from ANR (French Agency for Research) REPEAT grant (Special COVID-19), CNRS, IAST funding from the ANR under the Investments for the Future ("Investissements d'Avenir") program, grant ANR-17-EURE-0010, and Unicredit Foundation are gratefully acknowledged. The views expressed herein are those of the authors and do not necessarily reflect the views of the National Bureau of Economic Research.

NBER working papers are circulated for discussion and comment purposes. They have not been peer-reviewed or been subject to the review by the NBER Board of Directors that accompanies official NBER publications.

(C) 2020 by Vincenzo Galasso, Vincent Pons, Paola Profeta, Michael Becher, Sylvain Brouard, and Martial Foucault. All rights reserved. Short sections of text, not to exceed two paragraphs, may be quoted without explicit permission provided that full credit, including $\odot$ notice, is given to the source. 
Gender Differences in COVID-19 Related Attitudes and Behavior: Evidence from a Panel

Survey in Eight OECD Countries

Vincenzo Galasso, Vincent Pons, Paola Profeta, Michael Becher, Sylvain Brouard, and Martial Foucault

NBER Working Paper No. 27359

June 2020

JEL No. D70,D83,I12,I18

\section{$\underline{\text { ABSTRACT }}$}

Using original data from two waves of a survey conducted in March and April 2020 in eight OECD countries $(\mathrm{N}=21,649)$, we show that women are more likely to see COVID-19 as a very serious health problem, to agree with restraining public policy measures adopted in response to it, and to comply with them. Gender differences in attitudes and behavior are substantial in all countries, robust to controlling for a large set of sociodemographic, employment, psychological, and behavioral factors, and only partially mitigated for individuals who cohabit or have direct exposure to COVID-19. The results are not driven by differential social desirability bias. They carry important implications for the spread of the pandemic and may contribute to explain gender differences in vulnerability to it.

Vincenzo Galasso

Università Bocconi-IGIER

Milano, Italy

vincenzo.galasso@unibocconi.it

Vincent Pons

Harvard Business School

Morgan Hall 289

Soldiers Field

Boston, MA 02163

and NBER

vpons@hbs.edu

Paola Profeta

Università Bocconi

via Roentgen 1

20136 Milano

Italy

paola.profeta@ unibocconi.it
Michael Becher

Institute for Advanced Study in Toulouse

1, esplanade de l'Université

Toulouse 31080

France

michael.becher@iast.fr

Sylvain Brouard

CEVIPOF (Centre de recherches politiques)

98, rue de l'Université

Paris 75007

France

sylvain.brouard@sciencespo.fr

Martial Foucault

CEVIPOF (Centre de recherches politiques)

98 rue de l'Université

Paris 75007

France

martial.foucault@sciencespo.fr 
Large gender differences have emerged in mortality and vulnerability to COVID-19. Early studies of Wuhan, China, and Lombardy, Italy, two of the most affected regions, show a strong prevalence of hospitalization in ICUs among men (Grasseli et al., 2020; Chen et al,. 2020). Around the world, mortality rates among men have been as much as 50\% higher than among women (Wenham et al., 2020; Global Health). Conditional on being infected, men have been found to have a higher risk of severe illness and death. These gender differences also emerged in the earlier case of severe acute respiratory syndrome (SARS). A growing body of evidence suggests that the large gender disparities in vulnerability to COVID-19 may result in part from causes outside of the immediate control of individuals: genetic and immunological differences (Bianchi et al,. 2012; WHO 2007; Klein \& Flanagan, 2016); gender differences in pre-existing comorbidities; behavioral risk factors, such as a history of smoking (Wenham et al., 2020); and working conditions, with women being less active in the labor market, but often front-line providers of health and social care (Bertocchi, 2020). However, men and women may also differ in their attitudes towards the virus - namely, in their assessment of how dangerous it is and which policy measures should be adopted to combat it - and in their behavior-for instance, in their compliance with the health rules actually imposed by public authorities. Following the public management of the outbreak in China, many countries have advised or required restrictive measures, such as social distancing or wearing masks, in an attempt to contain the spread of COVID-19, limit pressure on their national health system, and, of course, reduce the death counts (Maharaj \& Kleczkowski, 2012). These measures have economic and psychological costs for the restrained individuals (Brooks et al., 2020). Yet, observance of public health rules has been shown to reduce both the individual risk of infection and hospitalization, as well as the likelihood of contaminating others (Leung et al., 2020; Kraemer et al., 2020). Gender differences in beliefs and behavior with respect to COVID-19 thus carry important implications for the spread of the pandemic and for the public policy (and communication) measures needed to curb it.

In this paper, we use original data from two waves of a nationally representative panel survey conducted online in eight OECD countries to analyze gender differences in beliefs and attitudes with respect to COVID-19 and in compliance with the public health rules adopted in response to it.

\section{Survey Data}

Our survey data (Brouard, Becher, et al., 2020) cover Australia $(\mathrm{N}=2010)$, Austria $(\mathrm{N}=2000)$, France $(\mathrm{N}=4036)$, Germany $(\mathrm{N}=3501)$, Italy $(\mathrm{N}=1997)$, New Zealand $(\mathrm{N}=1997)$, the United Kingdom $(\mathrm{N}=2012)$, and the United States $(\mathrm{N}=4096)$, for a total of 21,649 respondents. All these countries have high income per capita and advanced health systems, allowing us to pool their data in 
a common analysis, but they were affected very differently by the pandemic, increasing the external validity of our results. The United States, United Kingdom, and Italy are among the countries with the highest COVID-19 mortality in the world, while Australia and New Zealand each had fewer than 200 deaths (Worldometers.info) attributed to the pandemic by May 31, 2020.

The first wave of the survey was administered between March 16 and March 30, soon after the pandemic reached the countries we study. In this period, most of these countries were beginning to implement lockdowns and stay-at-home orders. ${ }^{1}$ The second wave was administered between April 15 and April 20. First-wave respondents were attempted again for the second wave. Those who failed to respond were replaced by new people. In each wave, respondents were asked how serious they expected the health consequences of COVID-19 to be in their country and whether they agreed with several public policy measures discussed or already implemented, such as closing schools, closing non-essential businesses, economic activities, and institutions, stopping public transportation, prohibiting meetings of two or more people, imposing quarantine on people entering the country, and closing borders. Respondents were also asked to report their current level of compliance with several COVID-19 related health and social distancing rules, such as washing hands, coughing into one's elbow, stopping hugging or greeting, keeping physical distance from others, staying at home, avoiding crowded places, and stopping meeting friends. Finally, the survey collected a wide range of sociodemographic and attitudinal factors.

\section{Gender Differences}

We observe large gender differences in the individual perception regarding the seriousness of COVID-19 as a health problem in the respondent's country. The data from the first wave in all eight countries in March $(\mathrm{N}=10,594)$ show that $59.0 \%$ of the female respondents considered COVID-19 to be a very serious health problem, against $48.7 \%$ of the men $(\mathrm{M}=0.590$ vs. 0.487 , Mdiff $=0.104$, $95 \%$ CI $[0.086 ; 0.121])$. In the pooled data from the second wave, in mid-April $(\mathrm{N}=11,025)$, these proportions had decreased by more than 15 percentage points among both men and women, but a sizable and significant gender difference remained $(\mathrm{M}=0.396$ vs. 0.330 , Mdiff $=0.067,95 \% \mathrm{CI}$ $[0.048 ; 0.085])$.

Figure 1 reports the share of men and women who considered COVID-19 to be a very serious health problem, by country, in the first wave (Panel A) and in the second wave (Panel B). This fraction largely varies across countries, from Austria, where less than one respondent out of three considered

\footnotetext{
${ }^{1}$ Table S1 in the Supplementary Material reports the lockdown date for each country.
} 
COVID-19 to be a serious health issue in March, to the U.K., where that proportion reaches $72 \%$ (first wave). The population's level of concern about the pandemic declined in all countries between March and April. These differences over space and time partly reflect differences in the actual magnitude of the pandemic. ${ }^{2}$ For all these differences, one pattern is nearly universal: except for the second wave in Austria, women were more likely than men to see COVID-19 as a very serious health problem in each wave and in each of the eight countries.

Does this stronger worry about COVID-19 induce women to be more in favor of restraining public policy measures? In both waves of our survey, respondents were asked how much they agree, on a 1-5 scale (from completely agree to completely disagree), with each of the following measures: closing schools, closing non-essential shops, postponing elections, prohibiting non-essential travels, stopping public transportation, using cellular phones to trace people's movements, imposing a curfew, imposing quarantine on people entering the country, closing borders, imposing self-quarantine at home, prohibiting meetings of two or more people, imposing quarantine away from home on people infected by COVID-19, and closing non-essential economic activities and institutions. ${ }^{3}$ In the second wave, individuals were also asked how much they agree with each of the two following additional measures: conducting systematic tests on the population and mandating the use of face masks in public places. We use respondents' answers to these questions to construct an overall index of their agreement with the restraining measures in each wave. Specifically, we create dummy variables equal to 1 if the respondent completely agrees with a measure and 0 otherwise, and we average them out over all questions.

Substantial gender differences are also present in individual attitudes towards these restraining measures. Pooling data from all countries in the first wave $(\mathrm{N}=10,600)$, our agreement index was larger among women than among men $(\mathrm{M}=0.541$ vs. 0.477 , Mdiff $=0.063,95 \% \mathrm{CI}[0.050 ; 0.077])$. In mid-April, pooled data $(\mathrm{N}=11,028)$ show that the overall agreement with restraining measures had decreased among both men and women, but a sizable and significant gender difference remained $(\mathrm{M}=0.426$ vs. 0.374 , Mdiff $=0.052,95 \%$ CI $[0.040 ; 0.064])$.

Figure 2 displays our agreement index by country, separately for men and women, at the end of March (panel A) and in mid-April (panel B). The range of agreement with restraining measures differs across countries, ranging from below $40 \%$ in the U.S. to nearly $65 \%$ in New Zealand in the first wave, and from $28 \%$ in Germany to nearly $55 \%$ in New Zealand in the second wave. Yet, in each country and

\footnotetext{
${ }^{2}$ Table S1 reports the number of deaths per million from COVID-19 in the different countries at the start of the first wave and the start of the second wave.

${ }^{3}$ See the Supplementary Material for the exact wording of the questions and the full list of questions asked in each wave and in each country.
} 
each wave, women were more likely to agree with these measures than men. As shown in Table S2, substantial and statistically significant gender differences exist in each wave for nearly each of the index's components. Some of the most important differences concern closing non-essential shops and postponing elections, in both waves, and mandating the use of face masks in public places, in the second wave.

We now turn to the most important outcome regarding public health: people's actual behavior with respect to the pandemic. As women everywhere are more concerned about the health consequences of COVID-19 and more favorable to activity-restraining public policy measures, we may expect them to also be more compliant with such measures. In both waves of our survey, individuals were asked to evaluate how strictly they were following seven recommended rules on a $0-10$ scale (from "not at all" to "completely"): washing hands more often, coughing into one's elbow, ending the greeting of people by shaking hands or hugging, avoiding crowed places, keeping physical distance from others, staying at home, and stopping visits to friends. In the second wave, respondents were also surveyed about the three following additional rules: wearing face masks in public places, wearing gloves in public places, and leaving home less than once a day. We construct an overall index of respondents' compliance with public health and social distancing rules in each wave by averaging out their answers to all questions after normalizing each of them on a $0-1$ range.

Once again, we observe important gender differences, this time in the compliance with rules. Pooling data from all eight countries in the first wave $(\mathrm{N}=10,602)$, compliance was markedly larger among women than among men $(\mathrm{M}=0.881$ vs. 0.832 , Mdiff $=0.049,95 \%$ CI $[0.042 ; 0.057])$. Pooled data $(\mathrm{N}=11,029)$ show that in mid-April general compliance had decreased (from 0.857 to 0.747 ) but remained at a high level. However, a sizable and significant gender difference persisted $(\mathrm{M}=0.776$ vs. 0.718 , Mdiff $=0.058,95 \%$ CI $[0.051 ; 0.065])$. Overall, the 4.9 and 5.8 percentage-point gender differences in behavior in the first and second waves are lower than the differences in beliefs about the pandemic (10.4 and 6.7 percentage points, respectively) and of a similar magnitude as the differences in agreement with restraining public measures (6.3 and 5.2 percentage points, respectively).

Figure 3 displays our compliance index separately for men and women by country in the first wave (panel A) and in the second wave (panel B). Differences across countries are smaller than for our two other outcomes. Yet, gender differences are still apparent, of comparable magnitude, and significant at the 5 percent level, in each wave and each country. ${ }^{4}$ Substantial differences exist in each wave for

\footnotetext{
${ }^{4}$ A recent paper studying the determinants of compliance in France finds women to be more compliant (Brouard, Vasilopoulos, et al., 2020).
} 
each of the index's components, but the behavior for which we observe the strongest difference between men and women is coughing into one's elbow (Table S3). Interestingly, this is also the one behavior which only serves the purpose of protecting others, whereas others can protect both oneself and others.

\section{Explanatory Factors}

Our data show consistent gender differences in beliefs, attitudes, and behavioral response to the pandemic. What are the determinants of these differences?

Gender differences in sociodemographic characteristics or employment status may create different perceptions and induce different types of behavior. For instance, women may be more concerned about COVID-19 and more compliant with the rules if they are older, poorer, or in worse health conditions on average, or if they perform a type of economic activity for which the risk of contagion is higher (WHO 2007; Boniol et al., 2019). Further, housing size may affect the costs associated with complying with measures that require people to stay at home, and people's religion may affect their beliefs on the seriousness of the pandemic and on the policies adopted in response to it. To account for these confounding factors, we regress each of our three variables of interest on the female dummy and a set of control variables: number of people per bedroom, and dummy variables for age groups, level of education, income quartiles, geographical location, employment status (full-time or part-time worker, self-employed, unemployed, or out of the labor force), type of occupation (blue collar, service, white collar, no occupation), population density, religion, and health status. ${ }^{5}$

Figure 4 plots estimates of gender differences in our pooled sample for the three main outcomes of interest, separately for the first wave (panel A) and the second wave (panel B), after controlling for these sociodemographic variables. We report the exact point estimates for the pooled sample in Table S4, and separately for each country in Tables S5-S7. The picture that emerges from this empirical evidence is overwhelming. Women remain much more likely than men to believe that the health consequences of the pandemic are very serious, in both waves, after controlling for a large number of sociodemographic characteristics and employment status. Women are also more supportive of the restraining measures and-most importantly-more compliant with the public health and social distancing measures once these variables are controlled for.

\footnotetext{
${ }^{5}$ We also control for ethnicity, in the U.S., and Aboriginal/non-Aboriginal, in Australia. Available controls vary across countries and waves. See the Supplementary Material for more details.
} 
We now investigate whether gender differences in psychological and behavioral factors help explain differences in perceptions and behaviors on COVID-19 related issues. We focus on four distinct factors. Two factors may affect people's willingness to adopt costly behavior in order to protect themselves and others: their perceived probability of becoming infected and their level of risk aversion. Two factors may influence their compliance with health rules proposed by the government to serve this objective: the level of trust towards scientists, who recommend the rules, and political ideology, which measures overall support for government intervention and affects the degree of alignment with the particular government in place at the time of the pandemic. We exploit four questions posed in both waves of our survey to measure these factors. Respondents were asked how difficult it is for them to accept health risks (on a $0-10$ scale), how much they trust scientists (on a $1-$ 4 scale, from "not at all" to "completely"), what is their political ideology (on a 0-10 scale, from left to right), and how likely they think they are to be infected if they go to work (on a 0-10 scale). We convert the responses to the trust in scientists to a dummy variable equal to 1 for the responses "somewhat" and "completely" and 0 otherwise, and we summarize the political ideology into three dummies for liberal (0-3), centrist (4-6), and conservative (7-10).

The existing literature shows that women are more risk-averse than men (Croson \& Gneezy, 2009) and that they are more left-leaning and more favorable to government intervention (Edlund \& Pande, 2002; Inglehart \& Norris, 2000). Results in Table S8 show that these differences are also present in the survey and that, in addition, women believe they are more likely to be infected. The latter difference may reflect objective gender differences in work environments or pre-existing health conditions as well as subjective differences in perception. Finally, the level of trust towards scientists is not significantly different between men and women.

The results of augmented regressions controlling for these four factors are shown in Figure 4 and in Table S4. Psychological and behavioral factors explain an important share of the variation in beliefs about the seriousness of the pandemic, and in agreement and compliance with the rules designed to combat it, as reflected by the increase in the R-squared. But the inclusion of these factors only reduces the gender effect modestly. Women remain more likely than men to believe that the consequences of the pandemic are serious and to agree with restraining rules and comply with them by $8.5,5.6$, and 4.9 percentage points, respectively, after controlling for sociodemographic characteristics and for the four psychological and behavioral factors. Point estimates on the female dummy are significant at the 1 percent level for all three outcomes. In sum, the rich and diverse set of factors that our regressions control for can only explain a small share of the observed differences between men and women. 


\section{Mitigating Factors}

Our results above identify gender-related factors which contribute (to a small extent) to explain the gender gap. We now explore which factors may reduce this gap. Differences in beliefs and behavior between men and women may decrease over time, if both groups are exposed to the same flow of information about the pandemic, they may be smaller among married couples, who live together and share their views with each other, and they may be smaller among individuals more directly exposed to the pandemic.

To test the first hypothesis, we regress our three outcomes of interest on the female dummy, time (a dummy for the second wave), and the interaction between this variable and the female dummy. The results are shown in Table 1, columns 1 through 3. Consistent with the graphical evidence in Figures 1 through 3 , beliefs on the seriousness of the pandemic, the agreement index, and the compliance index all decrease substantially over time. The gap between men and women is slightly lower in the second wave for the first two outcomes, but, if anything, the gender gap in compliance increases over time. In other words, the decrease in compliance with health measures is lower for women. As shown in Table S9, the results are robust to restricting the sample to individuals successfully surveyed in both waves of the panel (ensuring comparability over time) or to individuals who were only surveyed in one wave (so that, by construction, their responses cannot be biased by the desire to show consistency over time).

Columns 4 through 6 , and 7 through 9 of Table 1 test the two latter hypotheses by interacting the female dummy with a dummy indicating whether the individual lives alone or with other people (most individuals in the latter category are married with someone of the opposite gender) and two dummies indicating the level of exposure to the pandemic (having symptoms, or knowing someone with symptoms), respectively. All regressions pool the first and second waves together. Gender differences in our outcomes of interest are lower for individuals who live in a household than for those who live alone, consistent with the hypothesis that views on the pandemic and on appropriate health measures, as well as behavior, diffuse within households. This echoes evidence of similar transmission patterns for other types of beliefs and behavior, such as voting or using drugs (Nickerson, 2008; De Vaan \& Stuart, 2019). In addition, we find that people with COVID-19 symptoms and those who know others with such symptoms are more likely to comply with health measures, and that gender differences are smaller among them, suggesting that first-hand experience of the pandemic enables men to bridge part of the gap with women. ${ }^{6}$

\footnotetext{
${ }^{6}$ As shown in Table S10, we do not find a reduction in gender differences in regions with a higher fraction of cases or deaths, as measured at the time of each wave, indicating that the effect of gender is mitigated by first-hand experience of the pandemic, not by its overall prevalence.
} 
Finally, we test whether gender differences vary by age, income, and education. Columns 1 through 9 of Table S11 show the results obtained by interacting the female dummy with each of these factors separately, and columns 10 through 12 control for interactions with all of these factors. We find that differences in beliefs and behavior between men and women are lower among younger individuals and increase as people become older. This pattern may reflect an aging effect, due for instance to women being more likely to be socialized to become care-makers, or a cohort effect, if men and women receive a more similar education in younger cohorts. In addition, the gender difference in compliance with health and social distancing measures is lower among people with a higher income. Finally, we do not find any significant difference across different levels of education. Importantly, although the size of gender differences varies a bit across groups, these differences remain substantial and statistically significant for all the groups we consider and for all outcomes.

\section{Social Desirability Bias}

Because our analysis relies on survey data, a possible worry is that gender differences in self-declared compliance with health rules might result from differences in social desirability bias rather than in actual behavior. To address this concern, we exploit the results of a list experiment (also known as item-count technique), which was conducted in the second wave of the survey in all countries. ${ }^{7}$ The experiment focused on one specific behavior: meetings with people outside the household. Many countries required their populations to decrease the frequency of such meetings or to stop them altogether, and the World Health Organization recommended decreasing the number of interpersonal contacts as well (WHO, 2020). A first, randomly selected, half of respondents were presented with a list of five actions: "meeting with two or more friends or relatives who do not live with me" as well as four less sensitive actions. They were asked how many of these actions (from 0 to 5) they performed in the last week. Respondents who met with more than two people outside of their household could include it in the number they provided without revealing whether they had done that particular action or another one. ${ }^{8}$ This decreased the risk that their response would be biased by social desirability. The second half of respondents were presented with the list of four neutral actions, which did not include meeting with two or more people outside of their household. We can estimate the fraction of people who engaged in this activity by subtracting the average response in both groups. Formally, we regress the number of actions reported by respondents on a dummy equal to 1 if the list

\footnotetext{
${ }^{7}$ List experiments have been shown to elicit truthful answers to sensitive questions for a wide range of behaviors (Tsuchiya et al., 2007; Holbrook \& Krosnick, 2010; Coutts \& Jann, 2011).

${ }^{8}$ The answer of truthful respondents would only reveal that they met with more than two people outside of their household if they also performed all other actions. Very few people fall in this category: only $4 \%$ of respondents presented with the list of four neutral actions reported they performed all of them.
} 
they were presented included meeting with people outside their household. To estimate separately the fraction of men and women who engaged in this behavior, we control for the same dummy interacted with gender as well as the direct effect of gender. We report the results in Table 2. On average, 30.9 percent of the male respondents met with people outside their household. This fraction is 8.7 percentage points lower among women, a difference significant at the 5 percent level (column 1). This result is robust to allowing for differences in other sociodemographic factors (column 2).

We compare these effects to those obtained when asking respondents directly the extent to which they stopped seeing friends, which is one of the components of our overall compliance index. This question is in principle more susceptible to social desirability bias, as responding that one did not stop meeting with friends amounts to admitting a behavior which may be frowned upon and, in some countries, forbidden. We find an average level of compliance with this rule of $81.5 \%$ on a scale from 0 to 10 . More importantly, the difference between men and women is 6.4 percentage points, which is comparable to the difference found in the list experiment. The comparison between respondents' direct responses and the results of the list experiment assuages the concern that the gender differences we observe for this and other outcomes may be driven by differential social desirability bias.

\section{Discussion}

Our survey evidence convincingly points to strong gender differences in people's belief that COVID19 represents a very serious health risk, in their agreement with restraining policy measures, and in their compliance with public health rules. These differences persist over time, they are robust to controlling for sociodemographic indicators as well as psychological and behavioral factors, and they are only partially mitigated among individuals who live with others or who had direct exposure to COVID-19.

This result is in line with other gender differences uncovered in the scientific literature. In other fields as well, women have been found to be more agreeable (Bouchard \& Loehlin, 2001) and more compliant with the rules (Tittle, 1980; Torgler, 2007).

Our results may help to explain, at least in part, the gender differences that have emerged in mortality and vulnerability to COVID-19. By being more careful and compliant with the rules indicated by the WHO and by public authorities, women reduce the risk of being severely affected by COVID-19. Moreover, being more concerned, women may also be less reluctant than men to seek health care early on, when the first symptoms appear. These results also carry important policy implications for the public policy (and communication) measures needed to prevent COVID-19 diffusion. Because behavioral changes, from reduced mobility to wearing masks, might have to be 
accepted as the "new normal", at least for some time (Cohen \& Corey, 2020), differential public messages by gender may be required to increase compliance among men (Wenham et al., 2020). 


\section{References}

Bianchi, Ilaria., Ana Lleo, M. Eric Gershwin, and Pietro Invernizzi. The X chromosome and immune associated genes, Journal of Autoimmunity 38, J187-92 (May 2012).

Bertocchi, Graziella. COVID Susceptibility women and work. VOX (April 23, 2020).

Boniol, Mathieu, Michelle McIsaac, Lihui Xu, Tana Wuliji, Khassoum Diallo, and Jim Campbell. Gender equity in the health workforce: analysis of 104 countries: Health WorkforceWorking Paper 1. Geneva: World Health Organization. (March 2019).

Bouchard, Thomas and John Loehlin. Genes, evolution, and personality, Behavior Genetics 31, $243-$ 273 (May 2001).

Brooks, Samantha K., Rebecca K. Webster, Louise E. Smith, Lisa Woodland, Simon Wessely, Neil Greenberg, Gideon James Rubin. The psychological impact of quarantine and how to reduce it: rapid review of the evidence, The Lancet, 395, 912-920 (February 2020).

Brouard, Sylvain, Michael Becher, Martial Foucault, Pavlos Vasilopoulos. Citizens' attitudes towards COVID-19 - A comparative study (2020).

_ , Pavlos Vasilopoulos, and Michael Becher. Sociodemographic and psychological correlates of compliance with the Covid-19 public health measures in France, Canadian Journal of Political Science/Revue canadienne de science politique, 1-8 (2020).

Chen, Nanshen, Min Zhou, Xuan Dong, Jieming Qu, Fengyun Gong, Yang Han,..., Li Zhang. Epidemiological and clinical characteristics of 99 cases of 2019 novel coronavirus pneumonia in Wuhan, China: a descriptive study, The Lancet 395, 507-513 (January 2020).

Cohen, Myron S. and Lawrence Corey. Combination prevention for COVID-19, Science 368, 551 (May 2020).

Coutts, Elisabeth and Ben Jann. Sensitive Questions in Online Surveys: Experimental Results for the Randomized Response Technique (RRT) and the Unmatched Count Technique (UCT), Sociological Methods \& Research 40, 169-193 (January 2011).

Croson, Rachel and Uri Gneezy. Gender differences in preferences, Journal of Economic Literature 47, 448-74 (June 2009).

De Vaan, Mathijs and Toby Stuart. Does intra-household contagion cause an increase in prescription opioid use? American Sociological Review 84, 577-608 (June 2019). 
Edlund, Lena and Rohini Pande. Why have women become left-wing? The political gender gap and the decline in marriage, Quarterly Journal of Economics 117, 917-961 (August 2002).

Global Health 50/50. COVID-19 sex-disaggregated data tracker. https://globalhealth5050.org/covid19/sex-disaggregated-data-tracker/

Grasselli, Giacomo, Antonio Pesenti, and Maurizio Cecconi, Critical care utilization for the COVID19 outbreak in Lombardy, Italy: early experience and forecast during an emergency response, JAMA 323, 1545-1546 (March 2020).

Holbrook, Allyson L. and Jon A. Krosnick. Social Desirability Bias in Voter Turnout Reports: Tests Using the Item Count Technique, Public Opinion Quarterly 74, 37-67 (2010).

Inglehart, Ronald and Pippa Norris. The developmental theory of the gender gap: women's and men's voting behavior in global perspective, International Political Science Review 21, 441-463 (October 2000).

Klein, Sabra L., and Katie L. Flanagan. Sex differences in immune responses, Nature Reviews Immunology 16, 626-638 (August 2016).

Kraemer, Moritz U., Chia-Hung Yang, Bernardo Gutierrez, Chieh-Hsi Wu, Brennan Klein, David M., Pigott,... \& Samuel V. Scarpino. The effect of human mobility and control measures on the COVID-19 epidemic in China, Science 368, 493-497 (May 2020).

Leung, Nancy H.L., Daniel K. Chu, Eunice Y. Shiu, Kwok-Hung Chan, James J. McDevitt, Benien J.P. Hau, ... \& Benjamin J Cowling. Respiratory virus shedding in exhaled breath and efficacy of face masks, Nature Medicine 26, 676-680 (April 2020).

Maharaj, Savi and Adam Kleczkowski. Controlling epidemic spread by social distancing: do it well or not at all, BMC Public Health 12, 679 (August 2012).

Nickerson, David. Is voting contagious? Evidence from two field experiments, American Political Science review 102, 49-57 (February 2008).

Tittle, Charles. Sanctions and Social Deviance: The Question of Deterrence. New York: Praeger. (1980).

Torgler, Benno. Tax Compliance and Tax Morale: A Theoretical and Empirical Analysis. Edward Elgar. (2007).

Tsuchiya, Takahiro, Yoko Hirai, Shigeru Ono. A Study of the Properties of the Item Count Technique, Public Opinion Quarterly 71, 253-272 (June 2007). 
Wenham, Clare, Julia Smith, and Rosemary Morgan. COVID-19: the gendered impacts of the outbreak, The Lancet 395, 846-848 (March 2020).

World Health Organization. Addressing sex and gender in epidemic-prone infectious diseases. (2007).

World Health Organization. Coronavirus disease (COVID-19) advice for the public (2020). https://www.who.int/emergencies/diseases/novel-coronavirus-2019/advice-for-public.

Worldometers.info, www.worldometers.info/coronavirus/country. 
Fig. 1
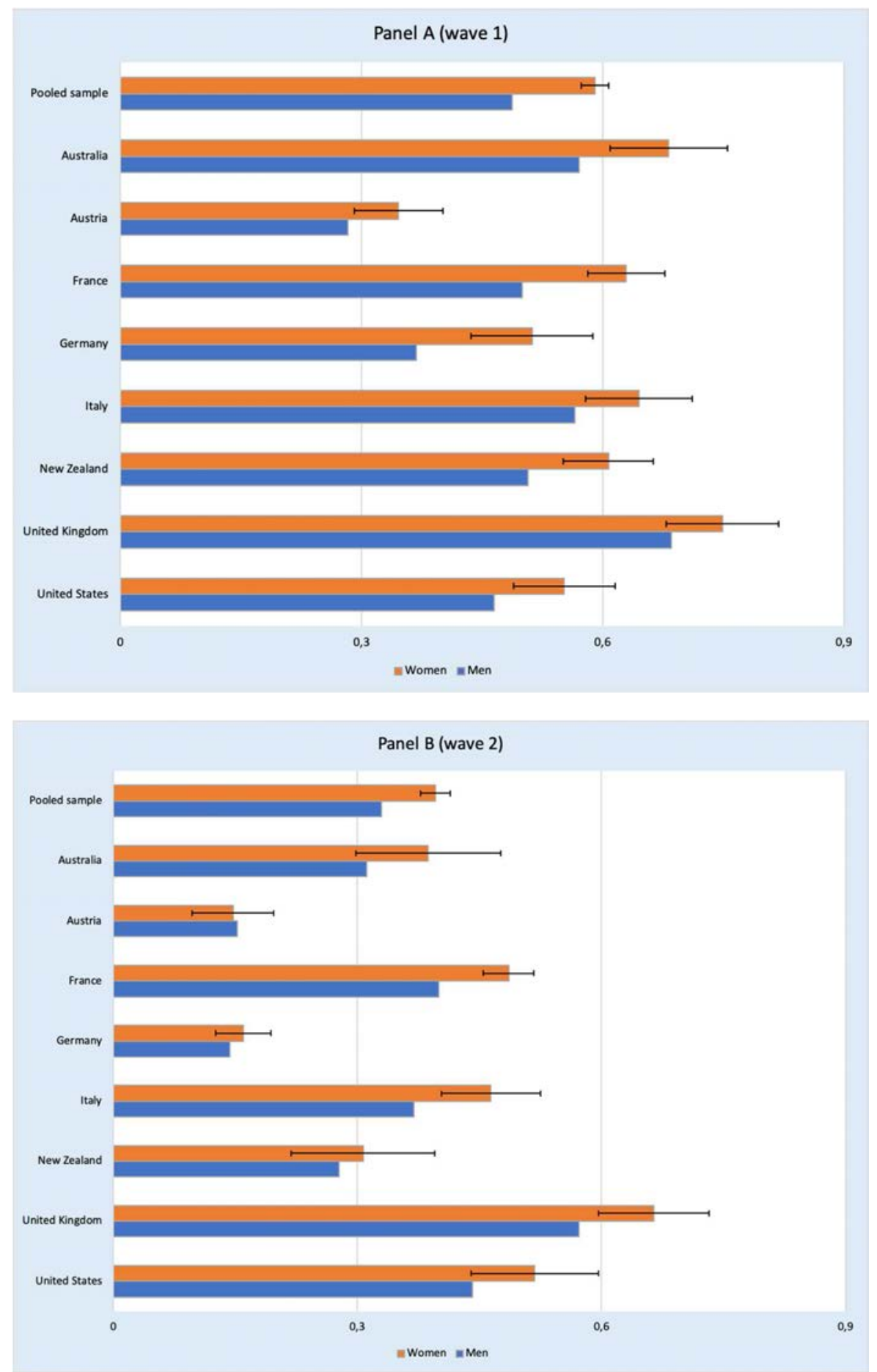

Notes: Share of men and women considering COVID-19 to be a very serious health problem, in the pooled sample and by country in the first and second wave (Panels A and B). We report 95\% confidence intervals from regressions of the dummy "very serious health problem" on female. 
Fig. 2.
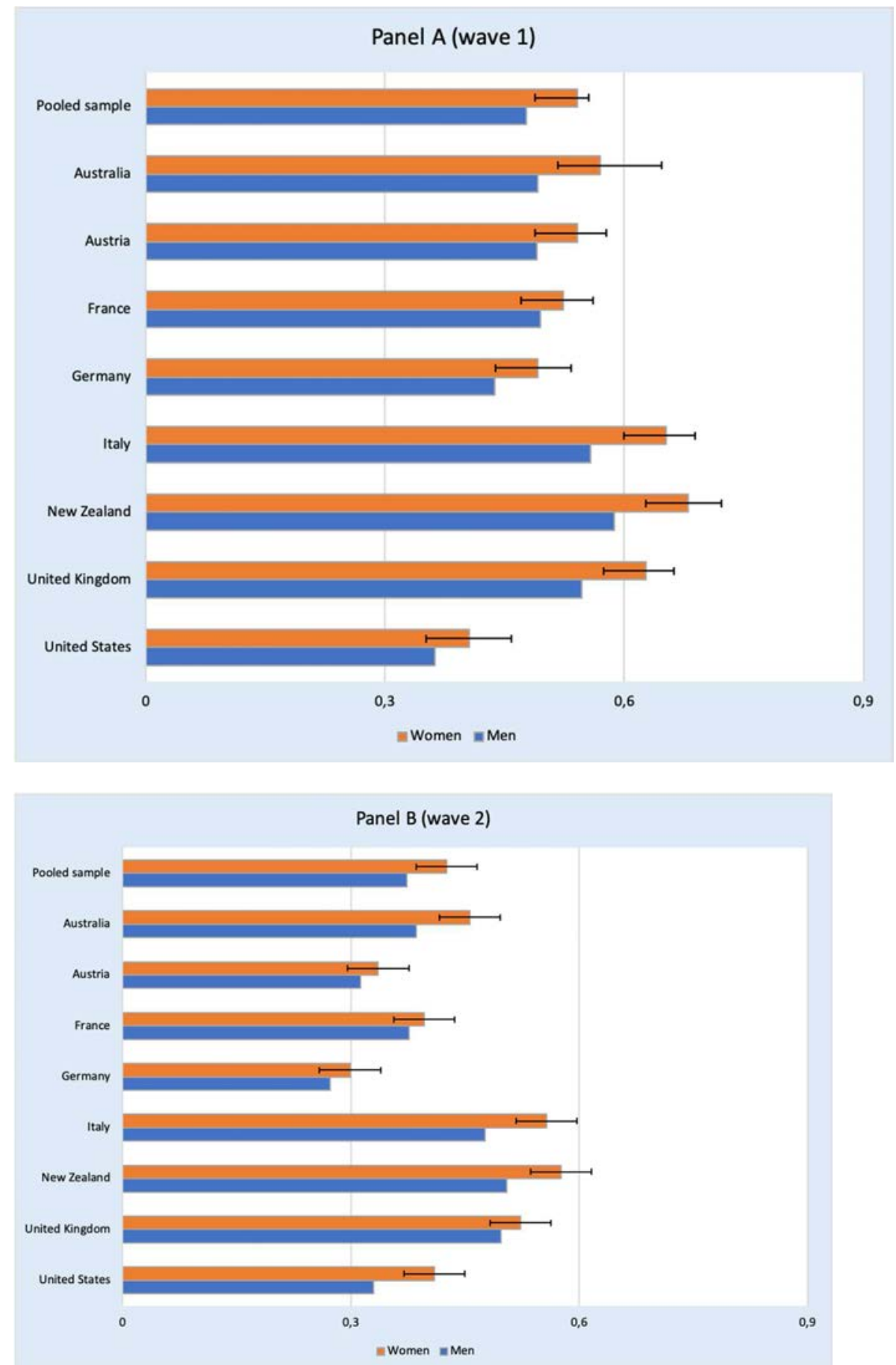

Notes: Agreement index for men and women, in the pooled sample and by country in the first and second wave (Panels A and B). We report 95\% confidence intervals from regressions of the agreement index on female. 
Fig. 3.
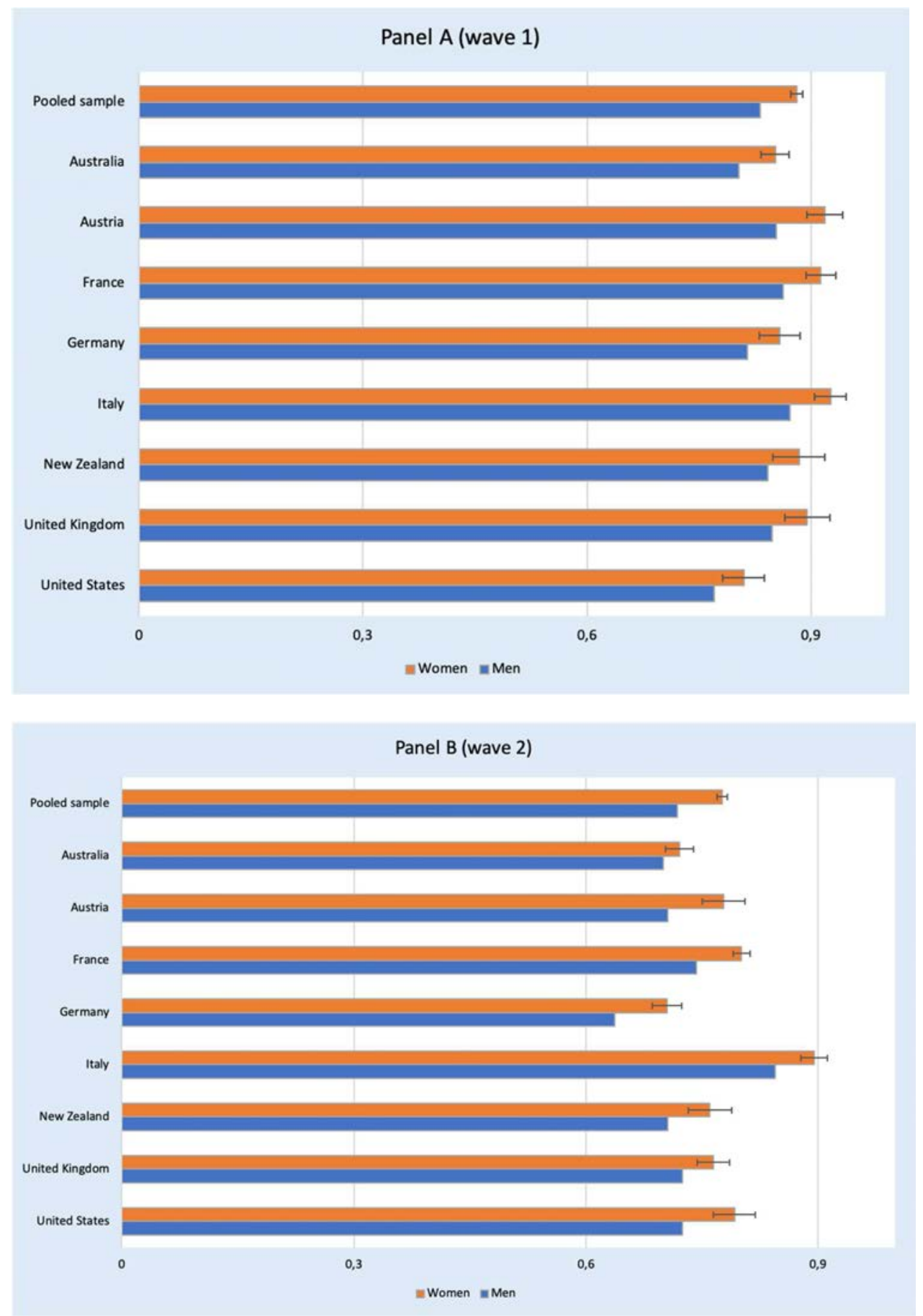

Notes: Compliance index for men and women, in the pooled sample and by country in the first and second wave (Panels A and B). We report 95\% confidence intervals from regressions of the compliance index on female. 
Fig. 4.
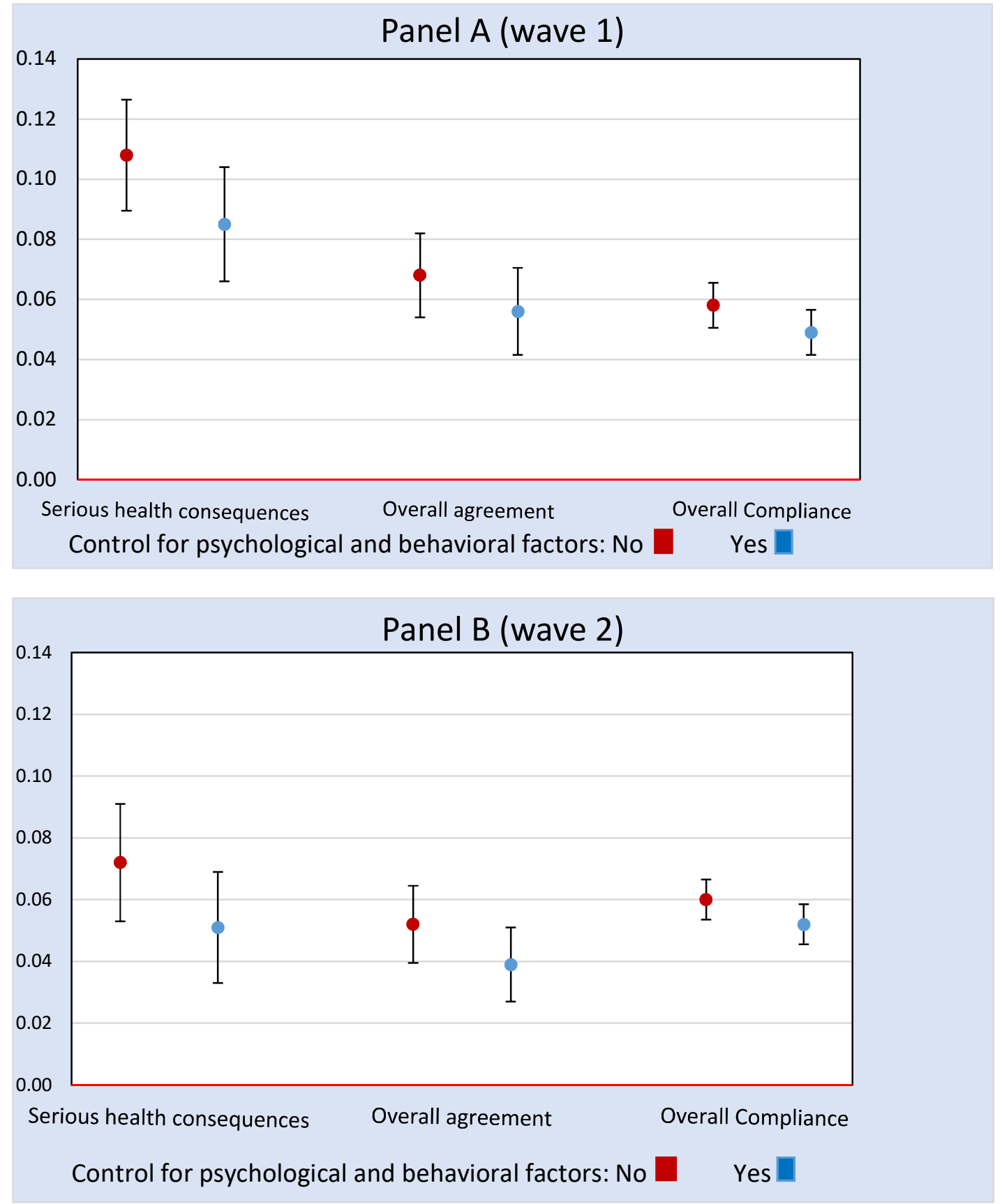

Notes: Point estimates of the female coefficient and 95\% confidence intervals, from regressions of "very serious health problem", the agreement index, and the compliance index on female. We use pooled data from the first and second wave (Panels A and B). Red estimates only control for sociodemographic factors. Blue estimates also control for psychological and behavioral factors. 
Table 1: Heterogeneous effects by time, living situation, and exposure to the pandemic

\begin{tabular}{|c|c|c|c|c|c|c|c|c|c|}
\hline & $\begin{array}{c}\text { Serious health } \\
\text { consequences } \\
\text { (1) }\end{array}$ & $\begin{array}{c}\text { Overall } \\
\text { agreement } \\
(2) \\
\end{array}$ & $\begin{array}{c}\text { Overall } \\
\text { compliance } \\
(3) \\
\end{array}$ & $\begin{array}{c}\text { Serious health } \\
\text { consequences } \\
\text { (4) }\end{array}$ & $\begin{array}{c}\text { Overall } \\
\text { agreement } \\
(5) \\
\end{array}$ & $\begin{array}{c}\text { Overall } \\
\text { compliance } \\
(6) \\
\end{array}$ & $\begin{array}{c}\text { Serious health } \\
\text { consequences } \\
\text { (7) }\end{array}$ & $\begin{array}{c}\text { Overall } \\
\text { agreement } \\
\text { (8) }\end{array}$ & $\begin{array}{c}\text { Overall } \\
\text { compliance } \\
(9) \\
\end{array}$ \\
\hline Female & $\begin{array}{c}0.101 \\
(0.009)^{* * *}\end{array}$ & $\begin{array}{c}0.065 \\
(0.007)^{* * *}\end{array}$ & $\begin{array}{c}0.054 \\
(0.004)^{* * *}\end{array}$ & $\begin{array}{c}0.107 \\
(0.017)^{* * *}\end{array}$ & $\begin{array}{c}0.071 \\
(0.012)^{* * *}\end{array}$ & $\begin{array}{c}0.070 \\
(0.007)^{* * *}\end{array}$ & $\begin{array}{c}0.088 \\
(0.010)^{* * *}\end{array}$ & $\begin{array}{c}0.060 \\
(0.006)^{* * *}\end{array}$ & $\begin{array}{c}0.061 \\
(0.003)^{* * *}\end{array}$ \\
\hline Female ${ }^{*}$ second wave & $\begin{array}{c}-0.027 \\
(0.011)^{* *}\end{array}$ & $\begin{array}{c}-0.012 \\
(0.007)^{*}\end{array}$ & $\begin{array}{c}0.008 \\
(0.004)^{*}\end{array}$ & & & & & & \\
\hline Second wave & $\begin{array}{c}-0.130 \\
(0.010)^{* * *}\end{array}$ & $\begin{array}{c}-0.091 \\
(0.007)^{* * *}\end{array}$ & $\begin{array}{c}-0.107 \\
(0.005)^{* * *}\end{array}$ & & & & & & \\
\hline Female * lives with others & & & & $\begin{array}{l}-0.029 \\
(0.020)\end{array}$ & $\begin{array}{l}-0.017 \\
(0.013)\end{array}$ & $\begin{array}{c}-0.015 \\
(0.008)^{*}\end{array}$ & & & \\
\hline Lives with others & & & & $\begin{array}{c}0.051 \\
(0.017)^{* * *}\end{array}$ & $\begin{array}{c}0.041 \\
(0.009)^{* * *}\end{array}$ & $\begin{array}{c}0.039 \\
(0.006)^{* * *}\end{array}$ & & & \\
\hline Female $*$ knows covid patients & & & & & & & $\begin{array}{l}-0.025 \\
(0.018)\end{array}$ & $\begin{array}{l}-0.004 \\
(0.013)\end{array}$ & $\begin{array}{c}-0.014 \\
(0.005)^{* * *}\end{array}$ \\
\hline Female $*$ covid patient & & & & & & & $\begin{array}{c}0.011 \\
(0.030)\end{array}$ & $\begin{array}{c}0.015 \\
(0.019)\end{array}$ & $\begin{array}{c}-0.019 \\
(0.009)^{* *}\end{array}$ \\
\hline Knows covid patients & & & & & & & $\begin{array}{c}0.032 \\
(0.014)^{* *}\end{array}$ & $\begin{array}{l}-0.003 \\
(0.011)\end{array}$ & $\begin{array}{c}0.019 \\
(0.005)^{* * *}\end{array}$ \\
\hline Covid patient & & & & & & & $\begin{array}{c}0.005 \\
(0.022)\end{array}$ & $\begin{array}{c}0.002 \\
(0.016)\end{array}$ & $\begin{array}{c}0.017 \\
(0.007)^{* *}\end{array}$ \\
\hline Observations & 21,618 & 21,627 & 21,630 & 16,973 & 16,979 & 16,981 & 20,057 & 20,066 & 20,069 \\
\hline R-squared & 0.131 & 0.123 & 0.200 & 0.141 & 0.128 & 0.215 & 0.140 & 0.134 & 0.215 \\
\hline Area fixed effects & Yes & Yes & Yes & Yes & Yes & Yes & Yes & Yes & Yes \\
\hline Wave fixed effects & Yes & Yes & Yes & Yes & Yes & Yes & Yes & Yes & Yes \\
\hline Sociodemographic controls & Yes & Yes & Yes & Yes & Yes & Yes & Yes & Yes & Yes \\
\hline Mean among men & 0.406 & 0.424 & 0.773 & 0.406 & 0.424 & 0.773 & 0.406 & 0.424 & 0.773 \\
\hline
\end{tabular}


Table 2: Test for social desirability bias

\begin{tabular}{|c|c|c|}
\hline \multirow[t]{2}{*}{ Panel A: List experiment } & \multicolumn{2}{|c|}{ Number actions reported } \\
\hline & (1) & $(2)$ \\
\hline \multirow{2}{*}{ Treatment: five actions } & 0.309 & 0.304 \\
\hline & $(0.032)^{* * *}$ & $(0.029) * * *$ \\
\hline \multirow[t]{2}{*}{ Treatment $*$ female } & -0.087 & -0.076 \\
\hline & $(0.044)^{* *}$ & $(0.043)^{*}$ \\
\hline \multirow[t]{2}{*}{ Female } & -0.076 & -0.091 \\
\hline & $(0.030)^{* *}$ & $(0.030)^{* * *}$ \\
\hline Observations & 11,019 & 11,019 \\
\hline R-squared & 0.085 & 0.117 \\
\hline Wave & 2 & 2 \\
\hline Area fixed effects & Yes & Yes \\
\hline Sociodemographic controls & No & Yes \\
\hline Treatment $*$ Sociodemographic controls & No & Yes \\
\hline \multicolumn{3}{|l|}{ Panel B: Self-reported behavior } \\
\hline & \multicolumn{2}{|c|}{ Stopped seeing friends } \\
\hline & $(1)$ & $(2)$ \\
\hline \multirow[t]{2}{*}{ Female } & 0.064 & 0.065 \\
\hline & $(0.005)^{* * *}$ & $(0.005)^{* * *}$ \\
\hline Observations & 11,029 & 11,029 \\
\hline R-squared & 0.086 & 0.103 \\
\hline Wave & 2 & 2 \\
\hline Area fixed effects & Yes & Yes \\
\hline Sociodemographic controls & No & Yes \\
\hline Mean among men & 0.815 & 0.815 \\
\hline
\end{tabular}

Notes : Standard errors clustered at the region level are in parentheses $(* * *, * *, *$ indicate significance at 1,5 , and 10 percent, respectively). In Panel $A$, the treatment is a dummy equal to 1 if the respondent was presented with a list of five actions, including "meeting with two or more friends or relatives who do not live with me" and four non-sensitive actions; and 0 if the respondent was presented with the list of four neutral actions. We control for area fixed effects in all regressions, and for sociodemographic characteristics in column 2. In Panel A, column 2, we also control for sociodemographic characteristics interacted with the treatment dummy. Sociodemographic controls as in Table 1. 


\section{Online Appendix}

\section{Survey Data}

We use data from the REPEAT project (REpresentations, PErceptions and ATtitudes on the COVID-19): two waves of a survey which we conducted contemporaneously in eight OECD countries (Australia, Austria, France, Germany, Italy, New Zealand, the United Kingdom, and the United States). The first wave of the survey was administered between March 16 and March 30 in all eight countries by IPSOS and CSA on nationally representative samples. The second wave was administered between April 15 and April 20 on nationally representative samples. First-wave respondents were attempted again for the second wave, making the survey a panel. Those who failed to respond to the second wave were replaced by new respondents. The survey collects information on perceptions and individual behavior related to COVID-19 and to the public health measures discussed or actually adopted to limit the diffusion of the virus. Table S1 reports the days in which the two waves of the survey were conducted in each country, the number of observations, the number of deaths per million inhabitants on the first day of the first and second wave, and the first day of the lockdown (if any).

Our first outcome variable is obtained from the answers to the following question "Would you say that the consequences of the coronavirus epidemic for health in (your country) are today...?" Answers go from "very serious" to "not serious at all" on a 1-5 scale. Our outcome is a dummy variable equal to 1 if the responded "very serious" and 0 otherwise.

The second outcome variable is an index of agreement with some restraining measures discussed or applied in the countries included in the study. We construct this index using answers to the following set of questions: "Here is a list of measures that have been taken in some countries against the spread of coronavirus (N-Covid19). Do you agree with them?" (i) Closing daycares, schools and universities; (ii) Closing non-essential stores (bars and stores except for grocery stores and health care, etc.); (iii) Postponing elections; (iv) Prohibiting non-essential trips; (v) Closing public transportation; (vi) Using mobile phone data to control people's movements; (vii) Implementing a curfew and using police or the army to control people's movements; (viii) Health check and mandatory quarantine for people entering the country; (ix) The closing of the borders for foreign citizens; (x) A general lock-down prohibiting people from leaving home (except for medical reasons); (xi) Prohibiting groups of at least two people except members of the same household; (xii) Closing of all non-vital companies and institutions; (xiii) Mandatory quarantine for all contaminated patients in specific places outside their home. In the second wave, two more measures were added to the list: (i) Systematic testing for COVID-19; and (ii) Mandatory wearing of masks outside home. Answers go from "completely agree" to "completely disagree" on a 1-5 scale. For each question, we constructed a dummy variable equal to one if the response was "completely agree". For each wave, we created an agreement index by averaging these dummies for each respondent. In Austria and Germany, questions regarding three measures - (ix) The closing of the borders foreign citizens; (xii) Closing of all non-vital companies and institutions; (xiii) Mandatory quarantine for all contaminated patients in specific places outside their home - were asked only in the second wave. In France, the question on one measure - (iii) Postponing elections - was asked only in the second wave. In Austria, France and Germany, one more measure - on the closing of the EU borders - was included in the first wave. 
In Australia (in both waves) and in the US (only in the second wave), one more measure - on the closing of the State borders - was included.

The third outcome variable is an index of compliance with some public health and social distancing rules discussed or applied in the different countries. We construct this index using answers to the following set of questions: "Due to the coronavirus epidemic, in your daily life, would you say that...? (i) You are washing your hands more often and/or for a longer amount of time; (ii) You are coughing or sneezing into your elbow or a tissue; (iii) You have stopped greeting others by shaking hands, hugging or kissing; (iv) You keep a distance of six feet between yourself and other people outside your home; (v) You have reduced your trips outside of home; (vi) You avoid busy places (public transportation, restaurants, sports...); (vii) You have stopped seeing friends. In the second wave, three more measures were add to the list: (i) You wear a mask or protection over your nose and mouth when you are outside your home; (ii) You wear gloves when you are outside your home; and (iii) You leave your home less than once a day on average. Answers go from "not at all" to "completely" on a 0-10 scale. For each wave, we created a compliance index by averaging these answers after normalizing each of them on a $0-1$ range.

The survey also collected sociodemographic information, including respondents' gender, age, race, education, household composition, income, geographical location and the corresponding population density, employment status, type of occupation, health status, and religion. Employment status is unavailable in France, and type of occupation and population density were not recorded in the United States, Australia, and New Zealand. Religion was only collected in the second wave. Economic variables are measured as of January, before the start of the pandemic. In addition to the aforementioned variables, ethnicity was recorded, in the United States, and Aboriginal/non-Aboriginal in Australia. Besides gender, which is our main variable of interest, we use this information to construct the following variables, used as controls in our regressions: age groups (18-29, 30-39, 40-49, 50-59, 60-69, and 70+), income quartiles, education (no high school, high school, and college), occupation (blue collar, service worker, white collar, and no occupation), employment type (full-time worker, part-time worker, selfemployed, unemployed, and out of the labor force), health status (good), area density (low, middle, high), number of people per room or per bedroom, race (white, black, Latino, Asian), a dummy for Aboriginal, religion (no religion, Catholic, Christian not catholic, other), and area fixed effects. For each control variable, we also include a dummy equal to 1 when the control is missing or was not recorded.

To test whether gender differences can be accounted for by differences in psychological and behavioral factors, we use additional information collected in both waves on respondents' risk aversion, trust towards scientists, perceived probability of being infected, and political ideology. More specifically, we use answers to the question on how easy or difficult is it for you to accept taking risks in health matters (on a $0-10$ scale, with 0 being "very difficult" and 10 "very easy") to construct a measure of risk aversion. We use the question on whether individuals trust scientists (Yes or No) to create a dummy variable for trust in scientists. We use a question on the individuals' opinion about their likelihood to be infected by coronavirus if they continue to work or start working again at their usual workplace (on a 0-10 scale from "very unlikely" to "very likely") to construct a measure of the subjective probability of being infected. Finally, we use a question on the individual political ideology (on a scale from 0 to 10 , where 0 is left and 10 is right) to construct three dummy variables for liberal (0-3), centrist (4-6) and conservative (7-10). 
To perform our heterogeneity analysis, we use the following additional variables. First, we construct a dummy variable equal to 1 for respondents living with others and 0 for those living alone, using answers to the following question: "Which of the following statements best describes your living arrangement these days? (i) Alone; (ii) With spouse only; (iii) With spouse and children or grandchildren; (iv) With children or grandchildren only; (v) With other relatives or friends; (vi) With other unrelated individuals." Second, we construct dummy variables for knowing a (likely) COVID patient and for being infected oneself, using answers to the following question: "In the last few weeks, would you say about the coronavirus or the symptoms of coronavirus (fever, cough, difficulty breathing, fatigue). (i) You have/had them; (ii) Someone in your household has/had them; (iii) A family member or someone in your household has/had them; (iv) Someone among your friends or acquaintances (from school, work, etc.) has/had them; (v) None of those." The dummy COVID infected takes value one for those responding (i), while the dummy knowing someone with COVID takes value one for answers (ii), (iii) and (iv). Third, we construct dummies equal to 1 if the fraction of deaths (resp. cases) in the respondent's region is higher than the median in that country $\mathrm{x}$ wave. We define the fraction of deaths (resp. cases) as the total number of deaths (resp. cases) until the day preceding the survey, divided by the region's population. Daily data on the number of cases per region were obtained for all countries except for Austria and France. Daily data on the number of deaths per region were obtained for all countries except for New Zealand. In the United Kingdom, daily deaths data for the first wave are dated three days after the interview for Northern Ireland and Scotland. The country specific sources are as follows:

- Australia and United States: John Hopkins University - Coronavirus Resource Center (available at https://github.com/CSSEGISandData/COVID-19)

- Austria: Sozial Ministerium (data received by email)

- Canada: Public Health Agency of Canada (available at https://www150.statcan.gc.ca/n1/en/catalogue/1310076601)

- France: Santé Publique France (available at https://www.data.gouv.fr/fr/datasets/donnees-hospitalieres-relatives-a-lepidemie-decovid-19/)

- Germany: Robert Koch Institut (https://npgeo-corona-npgeode.hub.arcgis.com/datasets/dd4580c810204019a7b8eb3e0b329dd6 0)

- Italy: Protezione Civile (https://github.com/pcm-dpc/COVID-19)

- New Zealand: Ministry of Health (https://www.health.govt.nz/our-work/diseases-andconditions/covid-19-novel-coronavirus/covid-19-current-situation/covid-19-currentcases/covid-19-current-cases-details\#download)

- United Kingdom: Office of National Statistics (https://www.ons.gov.uk/peoplepopulationandcommunity/healthandsocialcare/causesofd eath/datasets/deathregistrationsandoccurrencesbylocalauthorityandhealthboard)

Finally, we exploit the results of a list experiment conducted in the second wave in all countries, to address the concern of social desirability bias by gender. In each country, respondents were randomly allocated to two groups. The first group was asked: "How many of these things have you done last week? You do not need to tell me which ones you have done, just how many. (i) I went to the doctor or to the hospital; (ii) I used public transportation to get to work; (iii) I exercised outdoors; (iv) I ordered food using an online delivery service." Responses varied from 0 (for respondents who had not done any of these activities in the past week) to 4 (for respondents who had done all four of them). The second group of respondents was asked the 
same question but presented with a list of five actions, including the four actions above as well as the following one: "(v) I met with two or more friends or relatives who do not live with me." In this group, responses varied from 0 to 5 .

\section{Specifications}

To measure the existence of a gender gap in our three outcomes of interest (belief about the seriousness of the health problem, agreement with restrictive measures, and compliance with health rules), we use OLS estimates of the following linear equation:

$$
y_{i}=\alpha+\beta F_{i}+X_{i}^{\prime} \gamma+C_{i}^{\prime} \delta+\sum_{a} \partial_{i}^{a}+w_{i}+\varepsilon_{i}(1)
$$

where $y_{i}$ is one of the outcomes of interest, $F_{i}$ is a dummy for female, $X_{i}$ is the vector of sociodemographic characteristics, $C_{i}$ is the vector of psychological and behavioural factors, $\partial_{i}^{a}$ are area fixed effects, and $w_{i}$ is a fixed effect for the second wave. The coefficient of interest, measuring the difference between men and women (conditional on the controls), is $\beta$. Standard errors are clustered at the region level. For country regressions, we use survey weights that ensure the representativeness of the survey at the national level. Regressions on the pooled sample are instead unweighted to prevent observations from large countries to be overwhelming. These specifications are used in Table 2, Panel B, and in Tables S2 through S8. Area fixed effects are included in all specifications; the second wave fixed effect is included in all specifications pooling observations of both waves; and sociodemographic controls and controls for psychological and behavioural factors are included when specified.

To perform our heterogeneity analysis and identify factors that may mitigate gender differences, we run the following linear equation:

$$
y_{i}=\alpha+\beta F_{i}+E_{i}{ }^{\prime} \mu+F_{i} \times E_{i}{ }^{\prime} \rho+X_{i}^{\prime} \gamma+C_{i}^{\prime} \delta+\sum_{a} \partial_{i}^{a}+w_{i}+\varepsilon_{i}(2),
$$

where $E_{i}$ is a vector of possible mitigating factors (time, living with others, exposure to the pandemic, age, income, education, and large fraction of COVID cases and deaths in the respondent's region). The coefficient of interest, measuring the differential effect of gender for respondents with characteristics $E_{i}$, is the vector $\rho$. Results of the estimates from this equation are reported in Table 1 (with time, living with others, and exposure to the pandemic as mitigating factors), Table S9 (with time as mitigating factor), Table S10 (with large fraction of COVID cases and deaths in the respondent's region as mitigating factors), and Table S11 (with age, income, and education as mitigating factors).

Finally, we analyse the results of the list experiment using the following equation:

$$
y_{i}=\alpha+\beta F_{i}+X_{i}^{\prime} \gamma+\theta T_{i}+\tau T_{i} \times F_{i}+T_{i} \times X_{i}^{\prime} \varphi+\sum_{a} \partial_{i}^{a}+\varepsilon_{i}(3)
$$

where $T_{i}$ is a dummy equal to 1 if the respondent was presented a list of five actions (including "meeting with two or more friends or relatives who do not live with me") and 0 if he or she was 
presented a list of four actions (excluding "meeting with two or more friends or relatives who do not live with me"). Conditional on the controls, $\theta$ (resp. $\theta+\tau$ ) estimate the fraction of men (resp. women) who met with two or more friends or relatives not living with them. The results are reported in Table 2, Panel A. To ensure that the difference between men and women estimated by $\tau$ does not capture the influence of a correlated factor, we control for sociodemographic factors as well as their interaction with the treatment dummy (column 2). 


\section{Additional Tables}

\section{Table S1: Sampling frame}

\begin{tabular}{|c|c|c|c|c|c|c|c|}
\hline & \multicolumn{2}{|c|}{ First wave } & \multicolumn{2}{|c|}{ Second wave } & \multirow[b]{2}{*}{$\begin{array}{c}\text { Lockdown } \\
\text { Date }\end{array}$} & \multirow[b]{2}{*}{$\begin{array}{c}\text { Deaths per } \\
\text { million at } \\
\text { first wave }\end{array}$} & \multirow[b]{2}{*}{$\begin{array}{c}\text { Deaths per } \\
\text { million at } \\
\text { second } \\
\text { wave } \\
\end{array}$} \\
\hline & Dates & Observations & Dates & Observations & & & \\
\hline Australia & $\begin{array}{l}27-28 \\
\text { March }\end{array}$ & 1,003 & $\begin{array}{l}\text { 15-20 } \\
\text { April }\end{array}$ & 1,007 & None & 0.52 & 2.52 \\
\hline Austria & $\begin{array}{l}24-26 \\
\text { March }\end{array}$ & 1,000 & $\begin{array}{l}\text { 15-18 } \\
\text { April }\end{array}$ & 1,000 & 16 March & 3.16 & 44.36 \\
\hline France & $\begin{array}{l}24-25 \\
\text { March }\end{array}$ & 2,020 & $\begin{array}{l}15-16 \\
\text { April }\end{array}$ & 2,016 & 17 March & 16.97 & 264.88 \\
\hline Germany & $\begin{array}{l}20-21 \\
\text { March }\end{array}$ & 1,501 & $\begin{array}{l}\text { 16-18 } \\
\text { April }\end{array}$ & 2,000 & 17 March & 0.81 & 48.82 \\
\hline Italy & $\begin{array}{l}27-30 \\
\text { March }\end{array}$ & 1,000 & $\begin{array}{l}15-17 \\
\text { April }\end{array}$ & 997 & 9 March & 151.33 & 358.60 \\
\hline $\begin{array}{l}\text { New- } \\
\text { Zealand }\end{array}$ & $\begin{array}{l}25-27 \\
\text { March }\end{array}$ & 999 & $\begin{array}{l}\text { 15-18 } \\
\text { April }\end{array}$ & 998 & None & 0.00 & 1.84 \\
\hline UK & $\begin{array}{l}25-26 \\
\text { March }\end{array}$ & 1,011 & $\begin{array}{l}\text { 15-17 } \\
\text { April }\end{array}$ & 1,001 & $23 \mathrm{March}$ & 6.98 & 193.07 \\
\hline USA & $\begin{array}{l}25-27 \\
\text { March } \\
\end{array}$ & 2,089 & $\begin{array}{l}16-18 \\
\text { April } \\
\end{array}$ & 2,007 & $\begin{array}{c}\text { State- } \\
\text { specific }\end{array}$ & 4.01 & 106.17 \\
\hline
\end{tabular}

\footnotetext{
${ }^{1}$ John Hopkins University, Coronavirus Resource Center - https://coronavirus.jhu.edu
} 
Table S2: Effects on agreement with restraining public policy measures, detailed outcomes

\begin{tabular}{|c|c|c|c|c|c|c|c|c|c|c|c|c|c|c|c|c|c|}
\hline \multicolumn{18}{|l|}{ Panel A: First wave } \\
\hline & $\begin{array}{c}\text { Overall } \\
\text { agreement }\end{array}$ & $\begin{array}{l}\text { Closing non- } \\
\text { essential } \\
\text { economic } \\
\text { activities and } \\
\text { institutions }\end{array}$ & $\begin{array}{l}\text { Closing non- } \\
\text { essential } \\
\text { shops }\end{array}$ & $\begin{array}{l}\text { Closing } \\
\text { schools }\end{array}$ & $\begin{array}{l}\text { Stopping } \\
\text { public } \\
\text { transportati } \\
\text { on }\end{array}$ & $\begin{array}{l}\text { Prohibiting } \\
\text { meeting of } \\
\text { two or } \\
\text { more } \\
\text { people }\end{array}$ & $\begin{array}{l}\text { Prohibiting } \\
\text { non- } \\
\text { essential } \\
\text { travels }\end{array}$ & $\begin{array}{l}\text { Postponing } \\
\text { elections }\end{array}$ & $\begin{array}{l}\text { Imposing } \\
\text { quarantine } \\
\text { on people } \\
\text { entering the } \\
\text { country }\end{array}$ & $\begin{array}{l}\text { Closing } \\
\text { borders }\end{array}$ & $\begin{array}{l}\text { Imposing } \\
\text { quarantine } \\
\text { on people } \\
\text { infected by } \\
\text { the } \\
\text { coronavirus }\end{array}$ & $\begin{array}{l}\text { Using } \\
\text { cellular } \\
\text { phones to } \\
\text { trace } \\
\text { people's } \\
\text { movements }\end{array}$ & $\begin{array}{l}\text { Imposing a } \\
\text { curfew }\end{array}$ & $\begin{array}{l}\text { Imposing } \\
\text { self- } \\
\text { quarantine } \\
\text { at home }\end{array}$ & $\begin{array}{l}\text { Closing } \\
\text { state } \\
\text { borders }\end{array}$ & $\begin{array}{l}\text { Closing EU } \\
\text { borders }\end{array}$ & \\
\hline & (1) & (2) & (3) & (4) & (5) & (6) & (7) & (8) & (9) & (10) & (11) & (12) & (13) & (14) & (15) & (16) & \\
\hline \multirow[t]{2}{*}{ Female } & 0.068 & 0.098 & 0.105 & 0.070 & 0.036 & 0.088 & 0.101 & 0.095 & 0.070 & 0.060 & 0.051 & 0.000 & 0.060 & 0.070 & 0.129 & 0.027 & \\
\hline & $(0.007)^{* * *}$ & $(0.015)^{* * *}$ & $(0.011)^{* * *}$ & $(0.010)^{* * *}$ & $(0.010)^{* * *}$ & $(0.010)^{* * *}$ & $(0.011)^{* * *}$ & $(0.011)^{* * *}$ & $(0.009)^{* * *}$ & $(0.012)^{* * *}$ & $(0.012)^{* * *}$ & $(0.008)$ & $(0.009)^{* * *}$ & $(0.011)^{* * *}$ & $(0.040)^{* * *}$ & $(0.011)^{* *}$ & \\
\hline Observations & 10,599 & 8,076 & 10,586 & 10,577 & 10,575 & 10,584 & 10,578 & 8,562 & 10,582 & 8,075 & 8,086 & 10,579 & 10,586 & 10,591 & 998 & 4,499 & \\
\hline R-squared & 0.097 & 0.095 & 0.080 & 0.076 & 0.061 & 0.098 & 0.078 & 0.140 & 0.119 & 0.103 & 0.065 & 0.050 & 0.066 & 0.053 & 0.069 & 0.037 & \\
\hline Wave & 1 & 1 & 1 & 1 & 1 & 1 & 1 & 1 & 1 & 1 & 1 & 1 & 1 & 1 & 1 & 1 & \\
\hline Area fixed effects & Yes & Yes & Yes & Yes & Yes & Yes & Yes & Yes & Yes & Yes & Yes & Yes & Yes & Yes & Yes & Yes & \\
\hline Sociodemographic controls & Yes & Yes & Yes & Yes & Yes & Yes & Yes & Yes & Yes & Yes & Yes & Yes & Yes & Yes & Yes & Yes & \\
\hline Mean among men & 0.477 & 0.463 & 0.551 & 0.615 & 0.299 & 0.493 & 0.601 & 0.524 & 0.657 & 0.611 & 0.541 & 0.184 & 0.356 & 0.319 & 0.512 & 0.610 & \\
\hline \multicolumn{18}{|l|}{ Panel A: Second wave } \\
\hline & $\begin{array}{c}\text { Overall } \\
\text { agreement }\end{array}$ & $\begin{array}{l}\text { Closing non- } \\
\text { essential } \\
\text { economic } \\
\text { activities and } \\
\text { institutions }\end{array}$ & $\begin{array}{l}\text { Closing non- } \\
\text { essential } \\
\text { shops }\end{array}$ & $\begin{array}{l}\text { Closing } \\
\text { schools }\end{array}$ & $\begin{array}{l}\text { Stopping } \\
\text { public } \\
\text { transportati } \\
\text { on }\end{array}$ & $\begin{array}{c}\text { Prohibiting } \\
\text { meeting of } \\
\text { two or } \\
\text { more } \\
\text { people }\end{array}$ & $\begin{array}{l}\text { Prohibiting } \\
\text { non- } \\
\text { essential } \\
\text { travels }\end{array}$ & $\begin{array}{l}\text { Postponing } \\
\text { elections }\end{array}$ & $\begin{array}{l}\text { Imposing } \\
\text { quarantine } \\
\text { on people } \\
\text { entering the } \\
\text { country }\end{array}$ & $\begin{array}{l}\text { Closing } \\
\text { borders }\end{array}$ & $\begin{array}{l}\text { Imposing } \\
\text { quarantine } \\
\text { on people } \\
\text { infected by } \\
\text { the } \\
\text { coronavirus }\end{array}$ & $\begin{array}{l}\text { Using } \\
\text { cellular } \\
\text { phones to } \\
\text { trace } \\
\text { people's } \\
\text { movements }\end{array}$ & $\begin{array}{l}\text { Imposing a } \\
\text { curfew }\end{array}$ & $\begin{array}{l}\text { Imposing } \\
\text { self- } \\
\text { quarantine } \\
\text { at home }\end{array}$ & $\begin{array}{l}\text { Closing } \\
\text { state } \\
\text { borders }\end{array}$ & $\begin{array}{l}\text { Conducting } \\
\text { systematic } \\
\text { tests on the } \\
\text { population }\end{array}$ & $\begin{array}{c}\text { Mandating } \\
\text { the use of } \\
\text { face masks } \\
\text { in public } \\
\text { places }\end{array}$ \\
\hline & (1) & (2) & (3) & (4) & (5) & (6) & (7) & (8) & (9) & (10) & (11) & (12) & (13) & (14) & (15) & (16) & (17) \\
\hline \multirow[t]{2}{*}{ Female } & 0.052 & 0.062 & 0.073 & 0.055 & 0.029 & 0.063 & 0.066 & 0.070 & 0.071 & 0.045 & 0.053 & -0.011 & 0.029 & 0.031 & 0.097 & 0.055 & 0.079 \\
\hline & $(0.006)^{* * *}$ & $(0.010)^{* * *}$ & $(0.011)^{* * *}$ & $(0.010) * * *$ & $(0.009)^{* * *}$ & $(0.010) * * *$ & $(0.010)^{* * *}$ & $(0.011)^{* * *}$ & $(0.010)^{* * * *}$ & $(0.010)^{* * *}$ & $(0.010)^{* * * *}$ & $(0.008)$ & $(0.008)^{* * * *}$ & $(0.009)^{* * *}$ & $(0.020)^{* * *}$ & $(0.010)^{* * *}$ & $(0.009) * * *$ \\
\hline Observations & 11,028 & 11,001 & 11,018 & 10,997 & 11,001 & 11,015 & 10,988 & 10,983 & 11,014 & 11,000 & 11,018 & 10,998 & 11,018 & 11,020 & 3,006 & 11,001 & 11,006 \\
\hline R-squared & 0.121 & 0.100 & 0.123 & 0.095 & 0.077 & 0.069 & 0.071 & 0.115 & 0.104 & 0.124 & 0.102 & 0.041 & 0.052 & 0.086 & 0.094 & 0.062 & 0.119 \\
\hline Wave & 2 & 2 & 2 & 2 & 2 & 2 & 2 & 2 & 2 & 2 & 2 & 2 & 2 & 2 & 2 & 2 & 2 \\
\hline Area fixed effects & Yes & Yes & Yes & Yes & Yes & Yes & Yes & Yes & Yes & Yes & Yes & Yes & Yes & Yes & Yes & Yes & Yes \\
\hline Sociodemographic controls & Yes & Yes & Yes & Yes & Yes & Yes & Yes & Yes & Yes & Yes & Yes & Yes & Yes & Yes & Yes & Yes & Yes \\
\hline Mean among men & 0.374 & 0.299 & 0.377 & 0.439 & 0.227 & 0.367 & 0.471 & 0.449 & 0.622 & 0.543 & 0.411 & 0.175 & 0.224 & 0.221 & 0.345 & 0.523 & 0.275 \\
\hline
\end{tabular}

Notes : Standard errors clustered at the region level are in parentheses $(* * *, * *, *$ indicate significance at 1,5 , and 10 percent, respectively). We control for area fixed effects and sociodemographic characteristics in all regressions. Sociodemographic controls as in Table 1. 
Table S3: Compliance with public health rules, detailed outcomes

\begin{tabular}{|c|c|c|c|c|c|c|c|c|c|c|c|}
\hline \multicolumn{12}{|l|}{ Panel A: First wave } \\
\hline & $\begin{array}{c}\text { Overall } \\
\text { compliance }\end{array}$ & $\begin{array}{c}\text { Washing } \\
\text { hands more } \\
\text { often }\end{array}$ & $\begin{array}{l}\text { Coughing } \\
\text { into one's } \\
\text { elbow }\end{array}$ & $\begin{array}{l}\text { Ending the } \\
\text { greeting of } \\
\text { people by } \\
\text { shaking } \\
\text { hands or } \\
\text { hugging } \\
\text { (4) }\end{array}$ & $\begin{array}{c}\text { Keeping } \\
\text { physical } \\
\text { distance } \\
\text { from others }\end{array}$ & $\begin{array}{l}\text { Staying at } \\
\text { home }\end{array}$ & $\begin{array}{l}\text { Avoiding } \\
\text { crowed } \\
\text { places }\end{array}$ & $\begin{array}{l}\text { Stopping } \\
\text { visits to } \\
\text { friends }\end{array}$ & & & \\
\hline Female & $\begin{array}{c}0.058 \\
(0.004)^{* * *}\end{array}$ & $\begin{array}{c}0.054 \\
(0.004)^{* * *}\end{array}$ & $\begin{array}{c}0.089 \\
(0.006)^{* * *}\end{array}$ & $\begin{array}{c}0.044 \\
(0.004)^{* * *}\end{array}$ & $\begin{array}{c}0.049 \\
(0.004)^{* * *}\end{array}$ & $\begin{array}{c}0.054 \\
(0.005)^{* * *}\end{array}$ & $\begin{array}{c}0.049 \\
(0.004)^{* * *}\end{array}$ & $\begin{array}{c}0.064 \\
(0.005)^{* * *}\end{array}$ & & & \\
\hline Observations & 10,601 & 10,601 & 10,601 & 10,601 & 10,601 & 10,601 & 10,601 & 10,601 & & & \\
\hline R-squared & 0.119 & 0.063 & 0.055 & 0.097 & 0.104 & 0.107 & 0.083 & 0.123 & & & \\
\hline Wave & 1 & 1 & 1 & 1 & 1 & 1 & 1 & 1 & & & \\
\hline Area fixed effects & Yes & Yes & Yes & Yes & Yes & Yes & Yes & Yes & & & \\
\hline Sociodemographic controls & Yes & Yes & Yes & Yes & Yes & Yes & Yes & Yes & & & \\
\hline Mean among men & 0.832 & 0.815 & 0.767 & 0.883 & 0.848 & 0.828 & 0.858 & 0.822 & & & \\
\hline \multicolumn{12}{|l|}{ Panel B: Second wave } \\
\hline & $\begin{array}{c}\text { Overall } \\
\text { compliance }\end{array}$ & $\begin{array}{c}\text { Washing } \\
\text { hands more } \\
\text { often }\end{array}$ & $\begin{array}{l}\text { Coughing } \\
\text { into one's } \\
\text { elbow }\end{array}$ & $\begin{array}{l}\text { Ending the } \\
\text { greeting of } \\
\text { people by } \\
\text { shaking } \\
\text { hands or } \\
\text { hugging } \\
(4)\end{array}$ & $\begin{array}{c}\text { Keeping } \\
\text { physical } \\
\text { distance } \\
\text { from others }\end{array}$ & $\begin{array}{l}\text { Staying at } \\
\text { home }\end{array}$ & $\begin{array}{l}\text { Avoiding } \\
\text { crowed } \\
\text { places }\end{array}$ & $\begin{array}{l}\text { Stopping } \\
\text { visits to } \\
\text { friends }\end{array}$ & $\begin{array}{c}\text { Wearing } \\
\text { face masks } \\
\text { in public } \\
\text { places }\end{array}$ & $\begin{array}{c}\text { Wearing } \\
\text { gloves in } \\
\text { public } \\
\text { places } \\
\\
(10)\end{array}$ & $\begin{array}{c}\text { Leaving } \\
\text { home less } \\
\text { than once a } \\
\text { day } \\
\text { (11) }\end{array}$ \\
\hline Female & $\begin{array}{c}0.060 \\
(0.003)^{* * *}\end{array}$ & $\begin{array}{c}0.049 \\
(0.004)^{* * *}\end{array}$ & $\begin{array}{c}0.090 \\
(0.006)^{* * *}\end{array}$ & $\begin{array}{c}0.045 \\
(0.004)^{* * *}\end{array}$ & $\begin{array}{c}0.047 \\
(0.004)^{* * *}\end{array}$ & $\begin{array}{c}0.060 \\
(0.005)^{* * *}\end{array}$ & $\begin{array}{c}0.058 \\
(0.004)^{* * *}\end{array}$ & $\begin{array}{c}0.065 \\
(0.005)^{* * *}\end{array}$ & $\begin{array}{c}0.060 \\
(0.009)^{* * *}\end{array}$ & $\begin{array}{c}0.052 \\
(0.008)^{* * *}\end{array}$ & $\begin{array}{c}0.069 \\
(0.008)^{* * *}\end{array}$ \\
\hline Observations & 11,029 & 11,029 & 11,029 & 11,029 & 11,029 & 11,029 & 11,029 & 11,029 & 11,029 & 11,029 & 11,029 \\
\hline R-squared & 0.170 & 0.050 & 0.054 & 0.081 & 0.109 & 0.132 & 0.079 & 0.103 & 0.280 & 0.179 & 0.091 \\
\hline Wave & 2 & 2 & 2 & 2 & 2 & 2 & 2 & 2 & 2 & 2 & 2 \\
\hline Area fixed effects & Yes & Yes & Yes & Yes & Yes & Yes & Yes & Yes & Yes & Yes & Yes \\
\hline Sociodemographic controls & Yes & Yes & Yes & Yes & Yes & Yes & Yes & Yes & Yes & Yes & Yes \\
\hline Mean among men & 0.718 & 0.796 & 0.746 & 0.884 & 0.844 & 0.797 & 0.842 & 0.815 & 0.427 & 0.333 & 0.692 \\
\hline
\end{tabular}


Table S4: Specifications controlling for sociodemographic characteristics as well as psychological and behavioral factors

\begin{tabular}{|c|c|c|c|c|c|c|c|c|c|}
\hline \multicolumn{10}{|l|}{ Panel A: First wave } \\
\hline & \multicolumn{3}{|c|}{ Serious health consequences } & \multicolumn{3}{|c|}{ Overall agreement } & \multicolumn{3}{|c|}{ Overall compliance } \\
\hline & (1) & (2) & (3) & (4) & (5) & (6) & (7) & (8) & (9) \\
\hline \multirow{2}{*}{ Female } & 0.104 & 0.108 & 0.085 & 0.063 & 0.068 & 0.056 & 0.049 & 0.058 & 0.049 \\
\hline & $(0.009)^{* * *}$ & $(0.010)^{* * *}$ & $(0.009)^{* * *}$ & $(0.007)^{* * *}$ & $(0.007)^{* * *}$ & $(0.007)^{* * *}$ & $(0.004)^{* * *}$ & $(0.004)^{* * *}$ & $(0.004)^{* * *}$ \\
\hline \multirow[t]{2}{*}{ Risk aversion } & & & 0.021 & & & 0.015 & & & 0.008 \\
\hline & & & $(0.002) * * *$ & & & $(0.001)^{* * *}$ & & & $(0.001)^{* * *}$ \\
\hline \multirow[t]{2}{*}{ Trust in scientists } & & & 0.051 & & & 0.068 & & & 0.073 \\
\hline & & & $(0.017)^{* * *}$ & & & $(0.013)^{* * *}$ & & & $(0.007)^{* * *}$ \\
\hline \multirow[t]{2}{*}{ Perceived likelihood to get infected } & & & 0.027 & & & 0.015 & & & 0.010 \\
\hline & & & $(0.002) * * *$ & & & $(0.001)^{* * *}$ & & & $(0.001)^{* * *}$ \\
\hline \multirow[t]{2}{*}{ Liberal } & & & 0.014 & & & -0.049 & & & 0.013 \\
\hline & & & $(0.019)$ & & & $(0.011)^{* * *}$ & & & $(0.005)^{* *}$ \\
\hline \multirow[t]{2}{*}{ Centrist } & & & 0.014 & & & -0.042 & & & 0.000 \\
\hline & & & $(0.014)$ & & & $(0.008)^{* * * *}$ & & & $(0.005)$ \\
\hline \multirow[t]{2}{*}{ Ideology: don't know } & & & 0.041 & & & -0.002 & & & 0.010 \\
\hline & & & $(0.018)^{* *}$ & & & $(0.011)$ & & & $(0.007)$ \\
\hline Observations & 10,594 & 10,593 & 10,593 & 10,600 & 10,599 & 10,599 & 10,602 & 10,601 & 10,601 \\
\hline R-squared & 0.011 & 0.097 & 0.136 & 0.010 & 0.097 & 0.138 & 0.020 & 0.119 & 0.183 \\
\hline Wave & 1 & 1 & 1 & 1 & 1 & 1 & 1 & 1 & 1 \\
\hline Area fixed effects & No & Yes & Yes & No & Yes & Yes & No & Yes & Yes \\
\hline Sociodemographic controls & No & Yes & Yes & No & Yes & Yes & No & Yes & Yes \\
\hline Psychological and behavioral factors & No & No & Yes & No & No & Yes & No & No & Yes \\
\hline Mean among men & 0.487 & 0.487 & 0.487 & 0.477 & 0.477 & 0.477 & 0.832 & 0.832 & 0.832 \\
\hline \multicolumn{10}{|l|}{ Panel B: Second wave } \\
\hline & \multicolumn{3}{|c|}{ Serious health consequences } & \multicolumn{3}{|c|}{ Overall agreement } & \multicolumn{3}{|c|}{ Overall compliance } \\
\hline & (1) & (2) & (3) & (4) & (5) & (6) & (7) & (8) & (9) \\
\hline \multirow[t]{2}{*}{ Female } & 0.067 & 0.072 & 0.051 & 0.052 & 0.052 & 0.039 & 0.058 & 0.060 & 0.052 \\
\hline & $(0.009)^{* * *}$ & $(0.010)^{* * *}$ & $(0.009) * * *$ & $(0.006)^{* * *}$ & $(0.006) * * *$ & $(0.006)^{* * *}$ & $(0.004)^{* * *}$ & $(0.003)^{* * *}$ & $(0.003)^{* * *}$ \\
\hline \multirow[t]{2}{*}{ Risk aversion } & & & 0.017 & & & 0.012 & & & 0.006 \\
\hline & & & $(0.002) * * *$ & & & $(0.001)^{* * *}$ & & & $(0.001)^{* * *}$ \\
\hline \multirow[t]{2}{*}{ Trust in scientists } & & & 0.030 & & & 0.055 & & & 0.056 \\
\hline & & & $(0.013)^{* *}$ & & & $(0.010)^{* * *}$ & & & $(0.005)^{* * *}$ \\
\hline \multirow[t]{2}{*}{ Perceived likelihood to get infected } & & & 0.027 & & & 0.017 & & & 0.012 \\
\hline & & & $(0.002)^{* * *}$ & & & $(0.001)^{* * *}$ & & & $(0.001)^{* * *}$ \\
\hline \multirow[t]{2}{*}{ Liberal } & & & 0.055 & & & 0.004 & & & 0.010 \\
\hline & & & $(0.017)^{* * *}$ & & & $(0.010)$ & & & $(0.005)^{* *}$ \\
\hline Centrist & & & 0.023 & & & -0.012 & & & -0.003 \\
\hline & & & $(0.011)^{* *}$ & & & $(0.009)$ & & & $(0.004)$ \\
\hline Ideology: don't know & & & 0.045 & & & 0.018 & & & 0.007 \\
\hline & & & $(0.017)^{* * *}$ & & & $(0.010)^{*}$ & & & $(0.006)$ \\
\hline Observations & 11,025 & 11,025 & 11,025 & 11,028 & 11,028 & 11,028 & 11,029 & 11,029 & 11,029 \\
\hline R-squared & 0.005 & 0.135 & 0.168 & 0.008 & 0.121 & 0.160 & 0.028 & 0.170 & 0.227 \\
\hline Wave & 2 & 2 & 2 & 2 & 2 & 2 & 2 & 2 & 2 \\
\hline Area fixed effects & No & Yes & Yes & No & Yes & Yes & No & Yes & Yes \\
\hline Sociodemographic controls & No & Yes & Yes & No & Yes & Yes & No & Yes & Yes \\
\hline Psychological and behavioral factors & No & No & Yes & No & No & Yes & No & No & Yes \\
\hline Mean among men & 0.330 & 0.330 & 0.330 & 0.374 & 0.374 & 0.374 & 0.718 & 0.718 & 0.718 \\
\hline
\end{tabular}

Notes : Standard errors clustered at the region level are in parentheses $\left(* * *, * *,{ }^{*}\right.$ indicate significance at 1,5 , and 10 percent, respectively). We control for area fixed effects and sociodemographic characteristics in columns 2, 3, 5, 6, 8, and 9, and also control for psychological and behavioral factors in columns 3, 6, and 9 . The effects of psychological and behavioral factors are reported. Sociodemographic controls as in Table 1. 
Table S5: Effects on serious health consequences, by country

\begin{tabular}{|c|c|c|c|c|c|c|c|c|c|}
\hline \multicolumn{10}{|l|}{ Panel A: First wave } \\
\hline & $\begin{array}{c}\text { Pooled sample } \\
\text { (1) } \\
\end{array}$ & $\begin{array}{c}\text { Australia } \\
(2)\end{array}$ & $\begin{array}{c}\text { Austria } \\
(3)\end{array}$ & $\begin{array}{c}\text { France } \\
(4)\end{array}$ & $\begin{array}{c}\text { Germany } \\
(5) \\
\end{array}$ & $\begin{array}{c}\text { Italy } \\
(6)\end{array}$ & $\begin{array}{c}\text { New Zealand } \\
(7)\end{array}$ & $\begin{array}{c}\text { United Kingdom } \\
\text { (8) }\end{array}$ & $\begin{array}{c}\text { United States } \\
\text { (9) }\end{array}$ \\
\hline \multirow[t]{2}{*}{ Female } & 0.108 & 0.137 & 0.078 & 0.115 & 0.150 & 0.083 & 0.103 & 0.087 & 0.098 \\
\hline & $(0.010)^{* * *}$ & $(0.032)^{* * *}$ & $(0.026)^{* * *}$ & $(0.026)^{* * *}$ & $(0.024)^{* * *}$ & $(0.034)^{* *}$ & $(0.023)^{* * *}$ & $(0.019)^{* * *}$ & $(0.023)^{* * *}$ \\
\hline Observations & 10,593 & 1,002 & 1,000 & 1,999 & 1,501 & 999 & 999 & 1,011 & 2,082 \\
\hline R-squared & 0.097 & 0.081 & 0.066 & 0.071 & 0.079 & 0.083 & 0.046 & 0.109 & 0.071 \\
\hline Wave & 1 & 1 & 1 & 1 & 1 & 1 & 1 & 1 & 1 \\
\hline Area fixed effects & Yes & Yes & Yes & Yes & Yes & Yes & Yes & Yes & Yes \\
\hline Sociodemographic controls & Yes & Yes & Yes & Yes & Yes & Yes & Yes & Yes & Yes \\
\hline Mean among men & 0.487 & 0.561 & 0.275 & 0.529 & 0.360 & 0.555 & 0.520 & 0.685 & 0.476 \\
\hline \multicolumn{10}{|l|}{ Panel B: Second wave } \\
\hline & $\begin{array}{c}\text { Pooled sample } \\
\text { (1) } \\
\end{array}$ & $\begin{array}{c}\text { Australia } \\
(2)\end{array}$ & $\begin{array}{c}\text { Austria } \\
\text { (3) }\end{array}$ & $\begin{array}{c}\text { France } \\
(4)\end{array}$ & $\begin{array}{c}\text { Germany } \\
(5)\end{array}$ & $\begin{array}{l}\text { Italy } \\
(6)\end{array}$ & $\begin{array}{c}\text { New Zealand } \\
(7)\end{array}$ & $\begin{array}{c}\text { United Kingdom } \\
\text { (8) }\end{array}$ & $\begin{array}{c}\text { United States } \\
\text { (9) }\end{array}$ \\
\hline \multirow[t]{2}{*}{ Female } & 0.072 & 0.116 & -0.003 & 0.076 & 0.031 & 0.098 & 0.046 & 0.110 & 0.123 \\
\hline & $(0.010)^{* * *}$ & $(0.047)^{* *}$ & $(0.025)$ & $(0.018)^{* * *}$ & $(0.016)^{*}$ & $(0.030)^{* * *}$ & $(0.043)$ & $(0.033)^{* * *}$ & $(0.028)^{* * *}$ \\
\hline Observations & 11,025 & 1,005 & 1,000 & 2,020 & 2,000 & 997 & 998 & 1,000 & 2,005 \\
\hline R-squared & 0.135 & 0.054 & 0.032 & 0.052 & 0.055 & 0.066 & 0.047 & 0.095 & 0.085 \\
\hline Wave & 2 & 2 & 2 & 2 & 2 & 2 & 2 & 2 & 2 \\
\hline Area fixed effects & Yes & Yes & Yes & Yes & Yes & Yes & Yes & Yes & Yes \\
\hline Sociodemographic controls & Yes & Yes & Yes & Yes & Yes & Yes & Yes & Yes & Yes \\
\hline Mean among men & 0.330 & 0.299 & 0.160 & 0.412 & 0.143 & 0.373 & 0.294 & 0.574 & 0.419 \\
\hline
\end{tabular}

Notes : Standard errors clustered at the region level are in parentheses (***,**, ${ }^{*}$ indicate significance at 1,5 , and 10 percent, respectively). We control for area fixed effects and sociodemographic characteristics in all regressions. Sociodemographic controls as in Table 1. 
Table S6: Effects on overall agreement, by country

\begin{tabular}{|c|c|c|c|c|c|c|c|c|c|}
\hline \multicolumn{10}{|l|}{ Panel A: First wave } \\
\hline & $\begin{array}{l}\text { Pooled sample } \\
\text { (1) }\end{array}$ & $\begin{array}{l}\text { Australia } \\
\text { (2) }\end{array}$ & $\begin{array}{l}\text { Austria } \\
\text { (3) }\end{array}$ & $\begin{array}{l}\text { France } \\
\text { (4) }\end{array}$ & $\begin{array}{l}\text { Germany } \\
(5)\end{array}$ & $\begin{array}{l}\text { Italy } \\
(6)\end{array}$ & $\begin{array}{c}\text { New Zealand } \\
(7)\end{array}$ & $\begin{array}{c}\text { United Kingdom } \\
(8)\end{array}$ & $\begin{array}{c}\text { United States } \\
(9)\end{array}$ \\
\hline \multirow[t]{2}{*}{ Female } & 0.068 & 0.095 & 0.065 & 0.032 & 0.057 & 0.089 & 0.096 & 0.097 & 0.068 \\
\hline & $(0.007)^{* * *}$ & $(0.034)^{* *}$ & $(0.017)^{* * *}$ & $(0.014)^{* *}$ & $(0.014)^{* * *}$ & $(0.019)^{* * *}$ & $(0.019)^{* * *}$ & $(0.016)^{* * *}$ & $(0.017)^{* * *}$ \\
\hline Observations & 10,599 & 1,003 & 1,000 & 1,999 & 1,501 & 999 & 998 & 1,011 & 2,088 \\
\hline R-squared & 0.097 & 0.071 & 0.060 & 0.034 & 0.045 & 0.084 & 0.073 & 0.075 & 0.054 \\
\hline Wave & 1 & 1 & 1 & 1 & 1 & 1 & 1 & 1 & 1 \\
\hline Area fixed effects & Yes & Yes & Yes & Yes & Yes & Yes & Yes & Yes & Yes \\
\hline Sociodemographic controls & Yes & Yes & Yes & Yes & Yes & Yes & Yes & Yes & Yes \\
\hline Mean among men & 0.477 & 0.486 & 0.484 & 0.488 & 0.430 & 0.554 & 0.601 & 0.545 & 0.360 \\
\hline \multicolumn{10}{|l|}{ Panel B: Second wave } \\
\hline & $\begin{array}{l}\text { Pooled sample } \\
\text { (1) }\end{array}$ & $\begin{array}{l}\text { Australia } \\
\text { (2) }\end{array}$ & $\begin{array}{c}\text { Austria } \\
\text { (3) }\end{array}$ & $\begin{array}{l}\text { France } \\
\text { (4) }\end{array}$ & $\begin{array}{l}\text { Germany } \\
\text { (5) }\end{array}$ & $\begin{array}{l}\text { Italy } \\
(6)\end{array}$ & $\begin{array}{c}\text { New Zealand } \\
\text { (7) }\end{array}$ & $\begin{array}{l}\text { United Kingdom } \\
\text { (8) }\end{array}$ & $\begin{array}{c}\text { United States } \\
\text { (9) }\end{array}$ \\
\hline \multirow[t]{2}{*}{ Female } & 0.052 & 0.089 & 0.027 & 0.023 & 0.037 & 0.080 & 0.078 & 0.039 & 0.080 \\
\hline & $(0.006)^{* * *}$ & $(0.029)^{* * *}$ & $(0.022)$ & $(0.010)^{* *}$ & $(0.015)^{* *}$ & $(0.023)^{* * *}$ & $(0.019)^{* * *}$ & $(0.022)^{*}$ & $(0.012)^{* * *}$ \\
\hline Observations & 11,028 & 1,007 & 1,000 & 2,020 & 2,000 & 997 & 998 & 1,000 & 2,006 \\
\hline R-squared & 0.121 & 0.072 & 0.062 & 0.029 & 0.039 & 0.069 & 0.061 & 0.060 & 0.090 \\
\hline Wave & 2 & 2 & 2 & 2 & 2 & 2 & 2 & 2 & 2 \\
\hline Area fixed effects & Yes & Yes & Yes & Yes & Yes & Yes & Yes & Yes & Yes \\
\hline Sociodemographic controls & Yes & Yes & Yes & Yes & Yes & Yes & Yes & Yes & Yes \\
\hline Mean among men & 0.374 & 0.388 & 0.314 & 0.373 & 0.264 & 0.472 & 0.513 & 0.493 & 0.340 \\
\hline
\end{tabular}

Notes : Standard errors clustered at the region level are in parentheses $(* * *, * *, *$ indicate significance at 1,5 , and 10 percent, respectively). We control for area fixed effects and sociodemographic characteristics in all regressions. Sociodemographic controls as in Table 1. 
Table S7: Effects on overall compliance, by country

\begin{tabular}{|c|c|c|c|c|c|c|c|c|c|}
\hline \multicolumn{10}{|l|}{ Panel A: First wave } \\
\hline & $\begin{array}{l}\text { Pooled sample } \\
\text { (1) }\end{array}$ & $\begin{array}{l}\text { Australia } \\
\text { (2) }\end{array}$ & $\begin{array}{l}\text { Austria } \\
\text { (3) }\end{array}$ & $\begin{array}{l}\text { France } \\
\text { (4) }\end{array}$ & $\begin{array}{l}\text { Germany } \\
(5)\end{array}$ & $\begin{array}{l}\text { Italy } \\
(6)\end{array}$ & $\begin{array}{c}\text { New Zealand } \\
(7)\end{array}$ & $\begin{array}{c}\text { United Kingdom } \\
(8)\end{array}$ & $\begin{array}{c}\text { United States } \\
(9)\end{array}$ \\
\hline \multirow[t]{2}{*}{ Female } & 0.058 & 0.061 & 0.075 & 0.046 & 0.062 & 0.052 & 0.044 & 0.058 & 0.064 \\
\hline & $(0.004)^{* * *}$ & $(0.010)^{* * *}$ & $(0.010)^{* * *}$ & $(0.004)^{* * *}$ & $(0.010)^{* * *}$ & $(0.011)^{* * *}$ & $(0.012)^{* * *}$ & $(0.013)^{* * *}$ & $(0.011)^{* * *}$ \\
\hline Observations & 10,601 & 1,003 & 1,000 & 1,999 & 1,501 & 999 & 999 & 1,011 & 2,089 \\
\hline R-squared & 0.119 & 0.076 & 0.124 & 0.064 & 0.092 & 0.100 & 0.056 & 0.124 & 0.115 \\
\hline Wave & 1 & 1 & 1 & 1 & 1 & 1 & 1 & 1 & 1 \\
\hline Area fixed effects & Yes & Yes & Yes & Yes & Yes & Yes & Yes & Yes & Yes \\
\hline Sociodemographic controls & Yes & Yes & Yes & Yes & Yes & Yes & Yes & Yes & Yes \\
\hline Mean among men & 0.832 & 0.803 & 0.851 & 0.873 & 0.809 & 0.873 & 0.852 & 0.846 & 0.774 \\
\hline \multicolumn{10}{|l|}{ Panel B: Second wave } \\
\hline & $\begin{array}{l}\text { Pooled sample } \\
\text { (1) }\end{array}$ & $\begin{array}{l}\text { Australia } \\
\text { (2) }\end{array}$ & $\begin{array}{c}\text { Austria } \\
\text { (3) }\end{array}$ & $\begin{array}{l}\text { France } \\
\text { (4) }\end{array}$ & $\begin{array}{l}\text { Germany } \\
\text { (5) }\end{array}$ & $\begin{array}{l}\text { Italy } \\
(6)\end{array}$ & $\begin{array}{c}\text { New Zealand } \\
\text { (7) }\end{array}$ & $\begin{array}{l}\text { United Kingdom } \\
\text { (8) }\end{array}$ & $\begin{array}{c}\text { United States } \\
\text { (9) }\end{array}$ \\
\hline \multirow[t]{2}{*}{ Female } & 0.060 & 0.030 & 0.076 & 0.059 & 0.073 & 0.045 & 0.060 & 0.046 & 0.069 \\
\hline & $(0.003)^{* * *}$ & $(0.008)^{* * *}$ & $(0.012)^{* * *}$ & $(0.006)^{* * *}$ & $(0.009)^{* * *}$ & $(0.008)^{* * *}$ & $(0.011)^{* * *}$ & $(0.010)^{* * *}$ & $(0.007)^{* * *}$ \\
\hline Observations & 11,029 & 1,007 & 1,000 & 2,020 & 2,000 & 997 & 998 & 1,000 & 2,007 \\
\hline R-squared & 0.170 & 0.073 & 0.117 & 0.084 & 0.105 & 0.125 & 0.099 & 0.090 & 0.131 \\
\hline Wave & 2 & 2 & 2 & 2 & 2 & 2 & 2 & 2 & 2 \\
\hline Area fixed effects & Yes & Yes & Yes & Yes & Yes & Yes & Yes & Yes & Yes \\
\hline Sociodemographic controls & Yes & Yes & Yes & Yes & Yes & Yes & Yes & Yes & Yes \\
\hline Mean among men & 0.718 & 0.699 & 0.703 & 0.749 & 0.634 & 0.846 & 0.704 & 0.724 & 0.731 \\
\hline
\end{tabular}

Notes : Standard errors clustered at the region level are in parentheses $(* * *, * *, *$ indicate significance at 1,5 , and 10 percent, respectively). We control for area fixed effects and sociodemographic characteristics in all regressions. Sociodemographic controls as in Table 1. 
Table S8: Gender differences in psychological and behavioral factors

\begin{tabular}{lcccccc}
\hline \hline & Risk aversion & $\begin{array}{c}\text { Perceived } \\
\text { likelihood to } \\
\text { get infected }\end{array}$ & $\begin{array}{c}\text { Trust in } \\
\text { scientists }\end{array}$ & Liberal & Centrist & $\begin{array}{c}\text { Ideology: } \\
\text { don't know }\end{array}$ \\
& $(1)$ & $(2)$ & $(3)$ & $(4)$ & $(5)$ & $(6)$ \\
\hline Female & 0.604 & 0.351 & 0.002 & 0.024 & 0.005 & 0.057 \\
& $(0.049)^{* * *}$ & $(0.042)^{* * *}$ & $(0.005)$ & $(0.007)^{* * *}$ & $(0.008)$ & $(0.005)^{* * *}$ \\
Observations & 21,630 & 21,630 & 21,630 & 21,630 & 21,630 & 21,630 \\
R-squared & 0.046 & 0.034 & 0.014 & 0.020 & 0.031 & 0.042 \\
Area fixed effects & Yes & Yes & Yes & Yes & Yes & Yes \\
Wave fixed effects & Yes & Yes & Yes & Yes & Yes & Yes \\
Mean among men & 5.440 & 4.709 & 0.868 & 0.197 & 0.446 & 0.066
\end{tabular}

Notes : Standard errors clustered at the region level are in parentheses $(* * *, * *, *$ indicate significance at 1 , 5 , and 10 percent, respectively). We pool survey data from the first and second waves together. We control for area fixed effects and wave fixed effects. 
Table S9: Heterogeneous effects by time, robustness to different subsamples

\begin{tabular}{|c|c|c|c|c|c|c|}
\hline & \multicolumn{3}{|c|}{ Respondents surveyed in both waves } & \multicolumn{3}{|c|}{ Respondents surveyed only once } \\
\hline & $\begin{array}{c}\text { Serious health } \\
\text { consequences } \\
\text { (1) }\end{array}$ & $\begin{array}{c}\text { Overall } \\
\text { agreement } \\
\text { (2) }\end{array}$ & $\begin{array}{c}\text { Overall } \\
\text { compliance } \\
\text { (3) }\end{array}$ & $\begin{array}{c}\text { Serious health } \\
\text { consequences } \\
\text { (4) }\end{array}$ & $\begin{array}{c}\text { Overall } \\
\text { agreement } \\
\text { (5) }\end{array}$ & $\begin{array}{c}\text { Overall } \\
\text { compliance } \\
\text { (6) }\end{array}$ \\
\hline \multirow[t]{2}{*}{ Female } & 0.113 & 0.071 & 0.058 & 0.089 & 0.060 & 0.050 \\
\hline & $(0.013)^{* * *}$ & $(0.009)^{* * *}$ & $(0.004)^{* * *}$ & $(0.014)^{* * *}$ & $(0.010)^{* * *}$ & $(0.006)^{* * *}$ \\
\hline \multirow[t]{2}{*}{ Female ${ }^{*}$ second wave } & -0.010 & -0.014 & 0.008 & -0.048 & -0.010 & 0.006 \\
\hline & $(0.012)$ & $(0.008)^{*}$ & $(0.005)^{*}$ & $(0.020)^{* *}$ & $(0.013)$ & $(0.007)$ \\
\hline \multirow[t]{2}{*}{ Second wave } & -0.128 & -0.088 & -0.109 & -0.203 & -0.236 & -0.198 \\
\hline & $(0.010)^{* * *}$ & $(0.007)^{* * *}$ & $(0.005)^{* * *}$ & $(0.043)^{* * *}$ & $(0.029)^{* * *}$ & $(0.015)^{* * *}$ \\
\hline Observations & 11,897 & 11,903 & 11,904 & 9,720 & 9,723 & 9,725 \\
\hline R-squared & 0.133 & 0.122 & 0.204 & 0.146 & 0.149 & 0.215 \\
\hline Area fixed effects & Yes & Yes & Yes & Yes & Yes & Yes \\
\hline Wave fixed effects & Yes & Yes & Yes & Yes & Yes & Yes \\
\hline Sociodemographic controls & Yes & Yes & Yes & Yes & Yes & Yes \\
\hline Mean among men & 0.406 & 0.424 & 0.773 & 0.406 & 0.424 & 0.773 \\
\hline
\end{tabular}

Notes : Standard errors clustered at the region level are in parentheses $(* * *, * *, *$ indicate significance at 1,5 , and 10 percent, respectively). We pool survey data from the first and second waves together. We control for area fixed effects, wave fixed effects, and sociodemographic characteristics in all regressions. Sociodemographic controls as in Table 1. 
Table S10: Heterogeneous effects by fraction of COVID-19 cases and deaths in the region

\begin{tabular}{|c|c|c|c|c|c|c|}
\hline & $\begin{array}{c}\text { Serious health } \\
\text { consequences } \\
\text { (1) }\end{array}$ & $\begin{array}{c}\text { Overall } \\
\text { agreement } \\
(2)\end{array}$ & $\begin{array}{c}\text { Overall } \\
\text { compliance } \\
\text { (3) }\end{array}$ & $\begin{array}{l}\text { Serious health } \\
\text { consequences } \\
\text { (4) }\end{array}$ & $\begin{array}{c}\text { Overall } \\
\text { agreement } \\
\text { (5) }\end{array}$ & $\begin{array}{c}\text { Overall } \\
\text { compliance } \\
\text { (6) }\end{array}$ \\
\hline \multirow[t]{2}{*}{ Female } & 0.094 & 0.056 & 0.061 & 0.097 & 0.062 & 0.057 \\
\hline & $(0.010) * * *$ & $(0.007)^{* * *}$ & $(0.004)^{* * *}$ & $(0.011)^{* * *}$ & $(0.008) * * *$ & $(0.005)^{* * *}$ \\
\hline \multirow[t]{2}{*}{ Female $*$ large fraction of deaths } & -0.011 & 0.002 & -0.007 & & & \\
\hline & $(0.014)$ & $(0.010)$ & $(0.005)$ & & & \\
\hline \multirow[t]{2}{*}{ Large fraction of deaths } & -0.025 & -0.009 & 0.001 & & & \\
\hline & $(0.015)^{*}$ & $(0.013)$ & $(0.010)$ & & & \\
\hline \multirow[t]{2}{*}{ Female * large fraction of cases } & & & & -0.015 & 0.015 & -0.001 \\
\hline & & & & $(0.020)$ & $(0.012)$ & $(0.006)$ \\
\hline \multirow[t]{2}{*}{ Large fraction of cases } & & & & -0.005 & -0.012 & -0.002 \\
\hline & & & & $(0.023)$ & $(0.018)$ & $(0.013)$ \\
\hline Observations & 19,621 & 19,631 & 19,633 & 15,296 & 15,305 & 15,308 \\
\hline R-squared & 0.136 & 0.106 & 0.199 & 0.131 & 0.140 & 0.192 \\
\hline Area fixed effects & Yes & Yes & Yes & Yes & Yes & Yes \\
\hline Wave fixed effects & Yes & Yes & Yes & Yes & Yes & Yes \\
\hline Sociodemographic controls & Yes & Yes & Yes & Yes & Yes & Yes \\
\hline Mean among men & 0.405 & 0.411 & 0.772 & 0.414 & 0.426 & 0.763 \\
\hline
\end{tabular}

Notes : Standard errors clustered at the region level are in parentheses $(* * *, * *, *$ indicate significance at 1,5 , and 10 percent, respectively). We pool survey data from the first and second waves together. Large fraction of deaths (resp. cases) is a dummy equal to 1 if the fraction of deaths (resp. cases) in the respondent's region is higher than the median in the same country $x$ wave. We control for area fixed effects, wave fixed effects, and sociodemographic characteristics in all regressions. Sociodemographic controls as in Table 1. 
Table S11: Heterogeneous effects by sociodemographic factors

\begin{tabular}{|c|c|c|c|c|c|c|c|c|c|c|c|c|}
\hline & $\begin{array}{c}\text { Serious } \\
\text { health } \\
\text { consequenc } \\
\text { es }\end{array}$ & $\begin{array}{c}\text { Overall } \\
\text { agreement }\end{array}$ & $\begin{array}{c}\text { Overall } \\
\text { compliance }\end{array}$ & $\begin{array}{c}\text { Serious } \\
\text { health } \\
\text { consequenc } \\
\text { es }\end{array}$ & $\begin{array}{c}\text { Overall } \\
\text { agreement }\end{array}$ & $\begin{array}{c}\text { Overall } \\
\text { compliance }\end{array}$ & $\begin{array}{c}\text { Serious } \\
\text { health } \\
\text { consequenc } \\
\text { es }\end{array}$ & $\begin{array}{c}\text { Overall } \\
\text { agreement }\end{array}$ & $\begin{array}{c}\text { Overall } \\
\text { compliance }\end{array}$ & $\begin{array}{c}\text { Serious } \\
\text { health } \\
\text { consequenc } \\
\text { es }\end{array}$ & $\begin{array}{c}\text { Overall } \\
\text { agreement }\end{array}$ & $\begin{array}{c}\text { Overall } \\
\text { compliance }\end{array}$ \\
\hline & (1) & (2) & (3) & (4) & (5) & (6) & (7) & (8) & (9) & (10) & (11) & (12) \\
\hline Female & $\begin{array}{c}0.049 \\
(0-015)^{* * *}\end{array}$ & $\begin{array}{c}0.045 \\
(0.010)^{* * *}\end{array}$ & $\begin{array}{c}0.045 \\
(0.005)^{* * *}\end{array}$ & $\begin{array}{c}0.080 \\
014)^{* * *}\end{array}$ & $\begin{array}{c}0.048 \\
(0.012)^{* * *}\end{array}$ & $\begin{array}{c}0.065 \\
(0.007)^{* * *}\end{array}$ & $\begin{array}{c}0.059 \\
(0.029)^{* *}\end{array}$ & $\begin{array}{c}0.053 \\
(0.020) * * *\end{array}$ & $\begin{array}{c}0.052 \\
(0.011)^{* * *}\end{array}$ & $\begin{array}{c}0.008 \\
(0.034)\end{array}$ & $\begin{array}{c}0.026 \\
(0.025)\end{array}$ & $\begin{array}{c}0.043 \\
(0.013)^{* * *}\end{array}$ \\
\hline Female $* 40$ to 59 years old & $\begin{array}{c}0.041 \\
(0.019)^{* *}\end{array}$ & $\begin{array}{c}0.017 \\
(0.013)\end{array}$ & $\begin{array}{c}0.018 \\
(0.006)^{* * *}\end{array}$ & & & & & & & $\begin{array}{c}0.042 \\
(0.019)^{* *}\end{array}$ & $\begin{array}{c}0.020 \\
(0.013)\end{array}$ & $\begin{array}{c}0.019 \\
(0.006)^{* * *}\end{array}$ \\
\hline Female * more than 60 years old & $\begin{array}{c}0.070 \\
(0.020)^{* * *}\end{array}$ & $\begin{array}{c}0.024 \\
(0.013)^{*}\end{array}$ & $\begin{array}{c}0.017 \\
(0.007)^{* *}\end{array}$ & & & & & & & $\begin{array}{c}0.070 \\
(0.020)^{* * *}\end{array}$ & $\begin{array}{c}0.026 \\
(0.013)^{*}\end{array}$ & $\begin{array}{c}0.016 \\
(0.008)^{* *}\end{array}$ \\
\hline 40 to 59 years old & $\begin{array}{c}0.090 \\
(0.017)^{* * *}\end{array}$ & $\begin{array}{c}0.039 \\
(0.012)^{* * *}\end{array}$ & $\begin{array}{c}0.032 \\
(0.007)^{* * *}\end{array}$ & & & & & & & $\begin{array}{c}0.090 \\
(0.017)^{* * *}\end{array}$ & $\begin{array}{c}0.039 \\
(0.012)^{* * *}\end{array}$ & $\begin{array}{c}0.032 \\
(0.007)^{* * *}\end{array}$ \\
\hline More than 60 years old & $\begin{array}{c}0.112 \\
(0.019)^{* * *}\end{array}$ & $\begin{array}{c}0.028 \\
(0.012)^{* *}\end{array}$ & $\begin{array}{c}0.049 \\
(0.008)^{* * *}\end{array}$ & & & & & & & $\begin{array}{c}0.112 \\
(0.019)^{* * *}\end{array}$ & $\begin{array}{c}0.028 \\
(0.012)^{* *}\end{array}$ & $\begin{array}{c}0.049 \\
(0.008)^{* * *}\end{array}$ \\
\hline Female $* 2$ nd income quartile & & & & $\begin{array}{c}0.024 \\
(0.020)\end{array}$ & $\begin{array}{c}0.029 \\
(0.014)^{* *}\end{array}$ & $\begin{array}{l}-0.002 \\
(0.009)\end{array}$ & & & & $\begin{array}{c}0.019 \\
(0.021)\end{array}$ & $\begin{array}{c}0.026 \\
(0.014)^{*}\end{array}$ & $\begin{array}{l}-0.003 \\
(0.009)\end{array}$ \\
\hline Female $* 3$ rd income quartile & & & & $\begin{array}{c}0.021 \\
(0.020)\end{array}$ & $\begin{array}{c}0.018 \\
(0.013)\end{array}$ & $\begin{array}{l}-0.005 \\
(0.008)\end{array}$ & & & & $\begin{array}{c}0.017 \\
(0.021)\end{array}$ & $\begin{array}{c}0.013 \\
(0.013)\end{array}$ & $\begin{array}{l}-0.007 \\
(0.008)\end{array}$ \\
\hline Female * 4 th income quartile & & & & $\begin{array}{l}-0.012 \\
(0.020)\end{array}$ & $\begin{array}{c}0.000 \\
(0.013)\end{array}$ & $\begin{array}{c}-0.023 \\
(0.009)^{* * *}\end{array}$ & & & & $\begin{array}{l}-0.020 \\
(0.021)\end{array}$ & $\begin{array}{l}-0.009 \\
(0.013)\end{array}$ & $\begin{array}{c}-0.026 \\
(0.009)^{* * *}\end{array}$ \\
\hline Female * income not reported & & & & $\begin{array}{l}-0.032 \\
(0.030)\end{array}$ & $\begin{array}{l}-0.004 \\
(0.019)\end{array}$ & $\begin{array}{l}-0.009 \\
(0.011)\end{array}$ & & & & $\begin{array}{l}-0.037 \\
(0.030)\end{array}$ & $\begin{array}{l}-0.006 \\
(0.020)\end{array}$ & $\begin{array}{l}-0.010 \\
(0.011)\end{array}$ \\
\hline 2nd income quartile & & & & $\begin{array}{c}-0.032 \\
(0.016)^{* *}\end{array}$ & $\begin{array}{l}-0.001 \\
(0.010)\end{array}$ & $\begin{array}{c}0.020 \\
(0.007)^{* * *}\end{array}$ & & & & $\begin{array}{c}-0.028 \\
(0.017)^{*}\end{array}$ & $\begin{array}{c}0.001 \\
(0.010)\end{array}$ & $\begin{array}{c}0.021 \\
(0.007)^{* * *}\end{array}$ \\
\hline 3rd income quartile & & & & $\begin{array}{c}-0.040 \\
(0.015)^{* *}\end{array}$ & $\begin{array}{c}0.005 \\
(0.010)\end{array}$ & $\begin{array}{c}0.032 \\
(0.006)^{* * *}\end{array}$ & & & & $\begin{array}{c}-0.035 \\
(0.016)^{* *}\end{array}$ & $\begin{array}{c}0.008 \\
(0.010)\end{array}$ & $\begin{array}{c}0.033 \\
(0.006)^{* * *}\end{array}$ \\
\hline 4th income quartile & & & & $\begin{array}{l}-0.024 \\
(0.016)\end{array}$ & $\begin{array}{c}0.027 \\
(0.010)^{* * *}\end{array}$ & $\begin{array}{c}0.047 \\
(0.007)^{* * *}\end{array}$ & & & & $\begin{array}{l}-0.017 \\
(0.017)\end{array}$ & $\begin{array}{c}0.033 \\
(0.010)^{* * *}\end{array}$ & $\begin{array}{c}0.049 \\
(0.007)^{* * *}\end{array}$ \\
\hline Income not reported & & & & $\begin{array}{c}0.020 \\
(0.026)\end{array}$ & $\begin{array}{c}0.006 \\
(0.016)\end{array}$ & $\begin{array}{c}0.032 \\
(0.010)^{* * *}\end{array}$ & & & & $\begin{array}{c}0.023 \\
(0.026)\end{array}$ & $\begin{array}{c}0.007 \\
(0.017)\end{array}$ & $\begin{array}{c}0.033 \\
(0.010)^{* * *}\end{array}$ \\
\hline Female * high school education & & & & & & & $\begin{array}{c}0.030 \\
(0.031)\end{array}$ & $\begin{array}{l}-0.005 \\
(0.020)\end{array}$ & $\begin{array}{c}0.007 \\
(0.012)\end{array}$ & $\begin{array}{c}0.036 \\
(0.032)\end{array}$ & $\begin{array}{l}-0.003 \\
(0.020)\end{array}$ & $\begin{array}{c}0.010 \\
(0.012)\end{array}$ \\
\hline Female * college education & & & & & & & $\begin{array}{c}0.040 \\
(0.030)\end{array}$ & $\begin{array}{c}0.021 \\
(0.020)\end{array}$ & $\begin{array}{c}0.008 \\
(0.012)\end{array}$ & $\begin{array}{c}0.054 \\
(0.032)^{*}\end{array}$ & $\begin{array}{c}0.027 \\
(0.021)\end{array}$ & $\begin{array}{c}0.017 \\
(0.012)\end{array}$ \\
\hline High school education & & & & & & & $\begin{array}{c}-0.039 \\
(0.022)^{*}\end{array}$ & $\begin{array}{l}-0.006 \\
(0.016)\end{array}$ & $\begin{array}{c}0.001 \\
(0.010)\end{array}$ & $\begin{array}{c}-0.041 \\
(0.022)^{*}\end{array}$ & $\begin{array}{l}-0.007 \\
(0.016)\end{array}$ & $\begin{array}{l}-0.002 \\
(0.010)\end{array}$ \\
\hline College education & & & & & & & $\begin{array}{c}-0.069 \\
(0.023)^{* * *}\end{array}$ & $\begin{array}{c}-0.051 \\
(0.016)^{* * *}\end{array}$ & $\begin{array}{c}0.005 \\
(0.010)\end{array}$ & $\begin{array}{c}-0.075 \\
(0.023)^{* * *}\end{array}$ & $\begin{array}{c}-0.054 \\
(0.016)^{* * *}\end{array}$ & $\begin{array}{c}0.000 \\
(0.010)\end{array}$ \\
\hline Observations & 21,618 & 21,627 & 21,630 & 21,618 & 21,627 & 21,630 & 21,618 & 21,627 & 21,630 & 21,618 & 21,627 & 21,630 \\
\hline R-squared & 0.132 & 0.123 & 0.200 & 0.131 & 0.123 & 0.200 & 0.131 & 0.123 & 0.200 & 0.132 & 0.124 & 0.201 \\
\hline Area fixed effects & Yes & Yes & Yes & Yes & Yes & Yes & Yes & Yes & Yes & Yes & Yes & Yes \\
\hline Wave fixed effects & Yes & Yes & Yes & Yes & Yes & Yes & Yes & Yes & Yes & Yes & Yes & Yes \\
\hline Sociodemographic controls & Yes & Yes & Yes & Yes & Yes & Yes & Yes & Yes & Yes & Yes & Yes & Yes \\
\hline Mean among men & 0.406 & 0.424 & 0.773 & 0.406 & 0.424 & 0.773 & 0.406 & 0.424 & 0.773 & 0.406 & 0.424 & 0.773 \\
\hline
\end{tabular}

together. We control for area fixed effects, wave fixed effects, and sociodemographic characteristics in all regressions. Sociodemographic controls as in Table 1. 